\title{
Activating the Publicscape. The case of Urban Gorillas
}

Veronika Antoniou, René Carraz, Yiorgos Hadjichristou, Teresa Tourvas

Urban Gorillas

urbangorillas.ngo@gmail.com

\begin{abstract}
Urban Gorillas, a Cyprus based NGO, emerged at the aftermath of the 2013 socioeconomic crisis where the notion of publicness was deeply shaken. A cross-examination of the public sphere has led the team to coin the term publicscape and identify working methodologies within this context. Urban Gorillas took on the role of a catalyst between underused public spaces and the society's uneasy relationship with the notion of publicness. The work, spontaneous in nature, temporarily transforms spaces while creating permanent human networks. The recurring temporariness that characterises the actions revokes activism in the social structure, revitalising physical spaces and inspiring an urban culture of participation.
\end{abstract}

Keywords: publicscape, public space, co-creation, urban activism, Cyprus

To cite this article:

Antoniou, V., Carraz, R., Hadjichristou, Y., Tourvas, T. (2019). Activating the Publicscape. The case of Urban Gorillas, The Journal of Public Space, 4(3), 87-II6, DOI I0.3289I/jps.v4i3.I223

This article has been double blind peer reviewed and accepted for publication in The Journal of Public Space.

(C) (5) This work is licensed under a Creative Commons Attribution - Non Commercial 4.0 International License https://creativecommons.org/licenses/by-nc/4.0/ 


\section{Introduction}

On the morning of 25 March 2013, anyone waking up in Cyprus had the opportunity to witness the results of the European Union's experiment on the island's bank depositors. On that day, savings on the two main Cypriot private banks were confiscated, a total of 10 billion euros, as an attempt to save the banking system. With the wake of the 2013 economic crisis and under the threat of a financial catastrophe, surprisingly and in contrast to other European countries, very few people manifested. Public protests were minimal, ascertaining the crashing realisation that the fundamental culture of a public sphere was missing.

The essential development of a social critique, the production and circulation of discourses, which are primordial aspects of public space, were missing. This incident was the cradle for the creation of Urban Gorillas (UG). It emerged as a reaction to the lack of publicness, at a time when democratic governance was under question and when civil society was in tatters. Given that in the Aristotelian perspective the city is the manifestation of the ethics and lives of citizens, a place where democracy emerges and as public spaces could be recalled as the "window into a city's soul" (Zukin, 1996, p. 260): how could we act to enforce this purpose of the city?

The circumstances in 2013, urged a multidisciplinary team of urban enthusiasts that later formed UG, to call for a new understanding of public culture and public life. A great inspiration to this endeavour were city ideals as those initiated in the 30's in the US such as Robert Park's proclamation: "if the city is the world which man created, it is the world in which he is henceforth condemned to live [...] in making the city, man has remade himself." (Park, 1967, p. 3), and the aspiration of the healthy urban society conceptualised by Lefebvre (1994) and interpreted by Purcell (20I3, p. 3 I8):

In urban society, urban space is not ruled by property rights and exchange value but by inhabitants who appropriate space, make it their own, and use it to meet their needs. Urban society draws inhabitants into the center, into vital urban spaces where they encounter each other and engage in collective and meaningful negotiations about what kind of city they desire.

\section{Public spaces in Cyprus}

UG emerged within this turbulent context and understanding, in a desire to find, to create, to connect, to catalyze and to redefine the role of the public in this context of a likely defective public space. Generally speaking, we observe a general uneasiness of Cypriots when using public spaces, but this comes as no surprise. Historically, or more specifically in the last $\mathbf{4 5 0}$ years, the notion of public space, both in its physical and social form has been conceivably impaired. It is possible that the Ottoman empire (I57I-1878) did not allow spheres of public activities due to the need to control the uprise of the island's communities and the succeeding British colonisation (1878-1960) did not intend to improve this urban parameter despite the modernisation that it brought to the island. Following this period, urban development was based on the worldwide trend of the modern movement, of which the outcomes are well known: cities designed for cars and the emergence of privatisation of public spaces, led to the aspect of social interactions in urban spaces was largely discarded (e.g. Jacobs, 196I). After the declaration of independence in 1960, the young government of Cyprus was busy with 
the internal conflicts between the Greek and Turkish Cypriot communities. The 1974 coup d'état, the Turkish invasion and the division of the island, further led to the failure of public administration and citizens to deal with the vital issue of the lack of public space.

Globally, the provision and management of urban public space have become increasingly privatised (Németh, 2009; Loukaitou-Sideris, 1993), hybrid spaces have emerged (Nissen, 2008) and we have become accustomed to a dearth of public space supply and usage within our communities and public culture. In recent years, Cyprus is no exception to the trend. The notion that public spaces in Cyprus are often underused and underutilised is a widely recognised problem among local citizens. A large-scale survey by UG, focusing on public spaces in Cyprus based on a random sample of I,000 representative urban Cypriots revealed that $6 \mathrm{I}, 4 \%$ of respondents had a "neutral" or "negative" view of their public spaces. Participants in focus groups related to the survey stated that lack of safety, cleanliness, and activities were reasons leading to their negative or neutral perceptions of urban public spaces (Carraz et al., 2018). Conversely, participants were attracted to visit semi-private public spaces such as malls and outdoor cafe seating areas that have been on the rise (Carraz and Antoniou, 2015).

\section{Public space seeks users}

For UG, public space is also a literal space: it is the need to create a physical space where social encounters and possibility of self-management is enabled. This has been a major challenge in UG's work as the intention was not limited to improve public spaces and advocate for democratic governance but also to activate citizens in this context. Therefore a major task, given the precarious relationship of people with public space, was to find users of public spaces, in other words, to find ways to engage the public into the discourse of the public sphere. This is a major concern in today's public space interventions, that is, the fundamental need to reconnect the public with spaces, with each other and to meet user needs. Improving the usage of our public spaces allows increased access to freedom to their users, as Carr et al. (I993, p. 43) stressed: "Public places afford casual encounters in the course of daily life that can bind people together and give their lives meaning and power".

Yet, current research has noted that a well-designed public space does not necessarily guarantee success in achieving those needs, numerous cases showed it is essential to create stimuli to encourage the public to actively engage with their surroundings, and in turn cause social interactions and intensify usage (Gehl, 20 I0; Hou, 20I0; Stevens, 2007; Schmidt and Németh, 2010). The generation of public spaces opportunities should be exciting, responsive and give meaning to the city spaces by the use of different design strategies, such as playful, inclusive, and bottom-up designs (Carr et al., 1993; Francis, 2003; Hambleton, 20I4; Merry and Carraz, 20I5). For instance, it has been suggested that the implementation of a design strategy with an "enjoyment factor" situated in the public realm will allow for a pleasurable experience (Hassenzahl et al., 20I3), leading back to intensified spatial usage and socialisation.

One way that UG responds to adding this layer of "enjoyment factor" is through the organisation of events and festivals in public, semi-public or even private spaces. This seems to be even more necessary when the situation is further affected by the 
conflicted nature of the sites. Issues surrounding the social, political and financial division and ensuing crisis currently affecting the island of Cyprus can momentarily be alleviated by these ephemeral festivities and events: gay and carnivalesque, human-centred and creative, these events revoke activism at its core, as just like a carnival, a festival is ultimately a momentary rejection of social hierarchies for the sake of pleasure.

\section{Activating the publicscape}

UG's relationship with the public realm has been ongoing, rendering actions that vary in scale, form, approach and impact. There is no one formula fits all, and each project is place-specific. Yet, the essence of every action remains fundamentally rooted in democratic values, through an exploration of diverse artistic forms that trigger the change of spatial and social perceptions. UG orchestrates actions from a bottom-up approach to transforming often ephemerally urban realms into public spaces. It negotiates between public and private, and often reverses these notions to transform spaces with limitless publicness into accessible urban hubs. This generates the raising of awareness for the public space and to script spontaneous, momentary urbanism and show alternative ways of creating sustainable cities.

UG projects follow the underlying idea of activation of the "Publicscape", a word we propose to coin here, a word that expresses not only the activation of public spaces but also of the people as an integral part of the process. Publicscape offers a wider view of the role of the public that extends from public space understood both as a metaphorical and spatial term to public relations and public governance. Adopting the term publicscape allows us an extensive perspective of the notion of public, so we can respond with solutions to physical settings that are primarily inclusive for all citizens, and create meaningful relationships within such spaces. Fixating our working methodologies on people who are often omitted in the design of public spaces (Mueller et al., 20I8), is the antidote to current development trends guided by the need for high capital margins for the investors to the detriment of other stakeholders of the process (Low and Smith, 20I3).

UG's desire is to inspire communities to produce and manage urban spaces themselves whether this takes place through urban design, planned events or informal urbanism. Within this framework, UG becomes the "middleground" between authorities and people and is the vision for a permanent remedy for the governance of healthy cities. Cohendet et al. (2010) put forward the idea of "middleground", as an essential element in the dynamics of a creative city. Their idea is that we should move away from the anatomy of the creative class (Florida, 2005) and focus instead on the anatomy of the creative city. The middleground consists of communities and collectives that are important in sustaining a creative milieu. It connects formal institutions (such as firms, universities, government bodies) to creative individuals outside any formal institution, as they function in entirely different modes and only rarely connect to each other. To activate the creative fabric of a city, the availability and quality of places, spaces and events, as well as networks of people are essential.

The lack of formal public spaces in the city as a result of the deficiency of a vision from the local administration has driven UG to seek unofficial ways of generating urban public environments. For instance, UG temporarily hijacked historical monuments during the "ФouбKoPolis" festival and transformed them from a mere point of reference in the 
city, visited solely by tourists, into vibrant public spaces and arenas of joy and public contact. "ФouбKóPolis" translates into English as "Bubble City" that was ironically the cheerful rebound of UG for the economic crisis at that time.

Throughout the annual neighbourhood event "Pame Kaimakli", UG collaborates with residents to introduce a series of "open" thematics that exemplify how contemporary artistic practices can bring about social cohesion in a given community. Through this socially engaged approach to contemporary artistic production, opportunities for expression to the wider community are created, and a sense of authorship and engagement is endorsed to the participants. During the "open houses", and "open courtyards" events, for example, private space was turned into a freely accessible urban public hub as cultural activities took place in the otherwise inaccessible private houses. The houses themselves, momentarily, became an essential active member of the urban fabric during the event, triggering encounters between people who otherwise would have remained complete strangers.

The condition of public spaces in Cyprus is further aggravated by the complex issues surrounding the Buffer Zone, a line dividing the island, generating uneasy edges of the two divided parts of the country. The implementation of UG events as a response to deal with this multifacet political issue brings to the forefront a scene of "common ground" where people can co-exist and reclaim a city created through positive synergies, forward momentums and dynamic collaborations. The search for such a "common ground" was evident during the "In-Communicado" project where urban rooftops across the two sides of Nicosia's Buffer Zone served as the arena of sociocultural activities while talkie-walkies, flashing lights and communication technologies, dissolved the border and the distance, bringing together two communities.

UG has therefore strived to acquire the role of a catalyst, an agent for change, a link between underused or non-existent public space, and the society's uneasy relationship within these spaces. In the physical context of non-space, UG identifies urban cracks, opportunities to create such connections, and generates the possibility of coming together without prescribed or fixed solutions. The activities described although temporal in their extent create a new layer of connections, and begin to galvanise communities into networks of not only shared physical space but also shared experiences, memories and participation.

\section{Conclusion}

Six years on, after the devastating economic crisis of 2013, the Cypriot government is still trying to re-enchant its broken economy. The lack of long-term and sustainable vision together with a series of rushed decisions have further exacerbated the problematic urbanisation and gentrification of our cities. The coasts are gradually being built up to accommodate the villas sold to the wealthy few, highrises and private marinas are used as passport-generating schemes, while natural habitats and rural areas are under threat.

And although public space and the public sphere are still visibly suffering, there is however a sprinkle of hope. Recent years have seen the creation of a growing number of small independent groups, raising a voice against the catastrophic effects of overtourism, over-construction, the environmental crisis, and the suffering of an ever- 
increasing number of asylum seekers. These voices of resistance are creating synergies, shaping expertise and enabling a support system against growing capital and social inequalities.

UG is carving out publicscape to catalyse situations and processes connecting people with spaces and questioning the current developments. The "spontaneous urbanism" approach allows for urban expressions to be informally injected within the cities and temporarily recuperate the lacklustre environment that has developed due to the lack of a social and public policy in urban planning. This permanent temporariness that characterises UG's actions, revokes activism in the social structure and renders UG as a catalyst of the public realm, revitalising physical spaces and inspiring an urban culture of participation. After all, the notion of recurring ephemerality establishes a notion of permanence and is how UG gradually embed itself in the Cypriot urban scene. Publicscaping is necessary and it should address the role of the different constituents of a healthy city: institutions, individuals and communities shaping together a healthy, socially inclusive and creative middleground.

\section{References}

Carr, S., Francis, M., Rivlin, L. and Stone A. (1993). Public Space. Cambridge University Press.

Carraz, R. and Antoniou, V. (20I5). Good, Bad and Ugly: Public Benches in the Old Walled City of Nicosia. Cyprus Dossier, 8, 46-48.

Carraz R., Antoniou, V., and Hadjichristou, Y. (Eds.) (2018) Green Urban Lab: Activating public spaces. University of Nicosia Press.

Cohendet, P., Grandadam, D., and Simon, L. (20I0). The anatomy of the creative city. Industry and innovation, I7 (I), 9I-III.

Florida, R. (2005). Cities and the creative class. Routledge.

Francis, M. (2003). Urban Open Space: Designing for User Needs. Island Press: US.

Gehl, J. (20I0). Cities for People. Island Press: Washington, D.C.

Hambleton, R. (20I4). Leading the inclusive city: Place-based innovation for a bounded planet. Policy Press.

Hassenzahl, M., Eckoldt, K., Diefenbach, S., Laschke, M., Len, E., and Kim, J. (20I3). Designing moments of meaning and pleasure. Experience design and happiness. International Journal of Design, 7 (3), $21-3 \mathrm{I}$.

Hou, J. (Ed.). (20I0). Insurgent public space: Guerilla urbanism and the remaking of contemporary cities. Routledge.

Jacobs, J. (1992). The death and life of great American cities. 196I. New York: Vintage.

Lefebvre, H. (20I4). Toward an architecture of enjoyment. University of Minnesota Press.

Loukaitou-Sideris, A. (1993). Privatisation of public open space: The Los Angeles experience. Town Planning Review, 64 (2), I39-I67.

Low, S., \& Smith, N. (Eds.). (20I3). The politics of public space. Routledge.

Merry, A. and Carraz, R. (20I5). Exploring the Social Impacts of Temporary, Playful and Artistic Interventions. The International Journal of Social, Political and Community Agendas in the Arts, 10 (4), 29-46. 
Németh, J. (2009). Defining a public: The management of privately owned public space. Urban studies, 46 (I I), 2463-2490.

Nissen, S. (2008). Urban transformation from public and private space to spaces of hybrid character. Sociologický časopis/Czech Sociological Review, 44 (06), I I 29-II 49.

Park, R. (1967). On social control and collective behavior: Selected papers. University of Chicago Press.

Purcell, M. (20/3). The right to the city: the struggle for democracy in the urban public realm. Policy \& Politics, 4 I (3), 3| |-327.

Mueller, J., Lu, H., Chirkin, A., Klein, B., \& Schmitt, G. (20I8). Citizen Design Science: A strategy for crowd-creative urban design. Cities, $72,18 \mathrm{I}-\mathrm{I} 88$.

Schmidt, S., \& Németh, J. (2010). Space, place and the city: Emerging research on public space design and planning. Journal of Urban Design, 15 (4), 453-457.

Stevens, Q. (2007). The Ludic City: Exploring the Potential of Public Spaces. Oxford: Routledge.

Zukin, S. (1996). The cultures of cities. Wiley-Blackwell.

\section{Urban Gorillas}

Urban Gorillas is an NGO based in Nicosia, Cyprus that is run by a multi-disciplinary team of urban enthusiasts who envision healthy and socially inclusive cities. We came together in 2013 to create projects and actions that bring new energy and inspire change in city spaces.

At a time when approximately half of the world's population are city dwellers, having a positive impact on our public spaces and making city life more sustainable has become ever more important for maintaining creative and healthy cities.

http://urbangorillas.org/ 


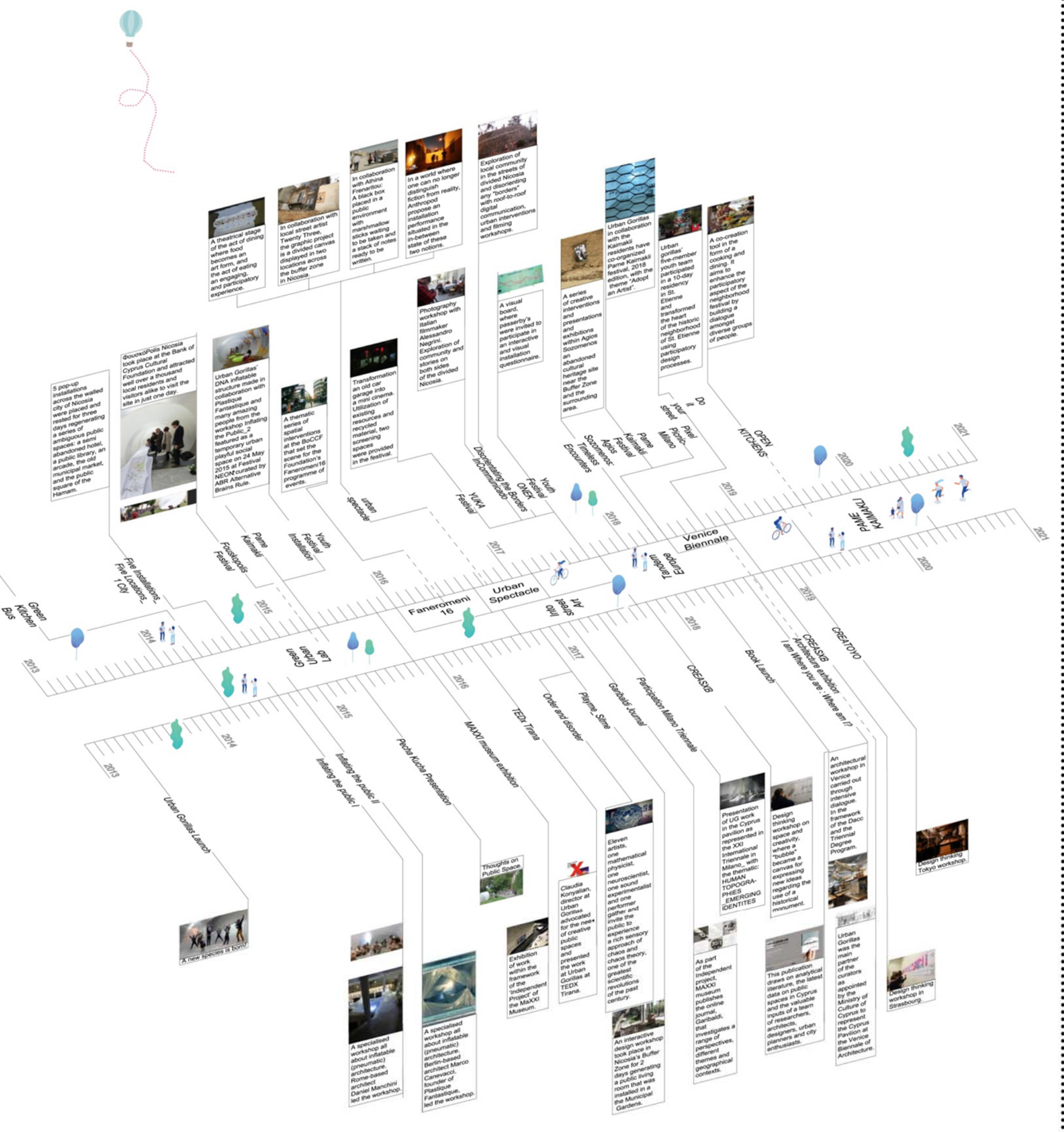




\section{Adopt an Artist}

(2018 edition of "Pame Kaimakli" festival)

http://urbangorillas.org/uncategorized/pame-kaimakli-adopt-an-artist/

Kaimakli is a neighborhood that lies on the east end of Nicosia against the Buffer Zone. Although only a few kilometers away from the city centre, its edge condition meant that for years it remained an isolated neighborhood. Until recently, the number of residents was gradually decreasing with mainly elderly and migrants choosing to live there. Due to the financial disparity and lack of interest in investing in the area, the traditionally built fabric survived modernisation and is now almost intact.

The traditional core of the neighborhood, resembling a village, features well-preserved stone courtyard houses that form a continuous vernacular fabric, with narrow streets, and a traditional church square. In the last decade, Kaimakli has been "re-discovered" by locals who want to live in the neighborhood, gradually renovating a number of houses, shops and studios, bringing a new culturally diverse layer to the area. The neighborhood became also the home of the studio of Urban Gorillas.

Despite the neighborhood dense and quaint built fabric, there are very few opportunities for social interaction. In 2013, an organised group of residents joined forces to organise "open" events in order to bring residents together and open up their beautiful neighborhood to visitors. A series of open events were organised, leading to the annual "Pame Kaimakli" -- Let's go Kaimakli -- festivals. During “Open Windows”, “Open Houses", and "Open courtyards," where otherwise inaccessible private spaces, homes and workplaces, opened up to the wider public creating a new public realm.

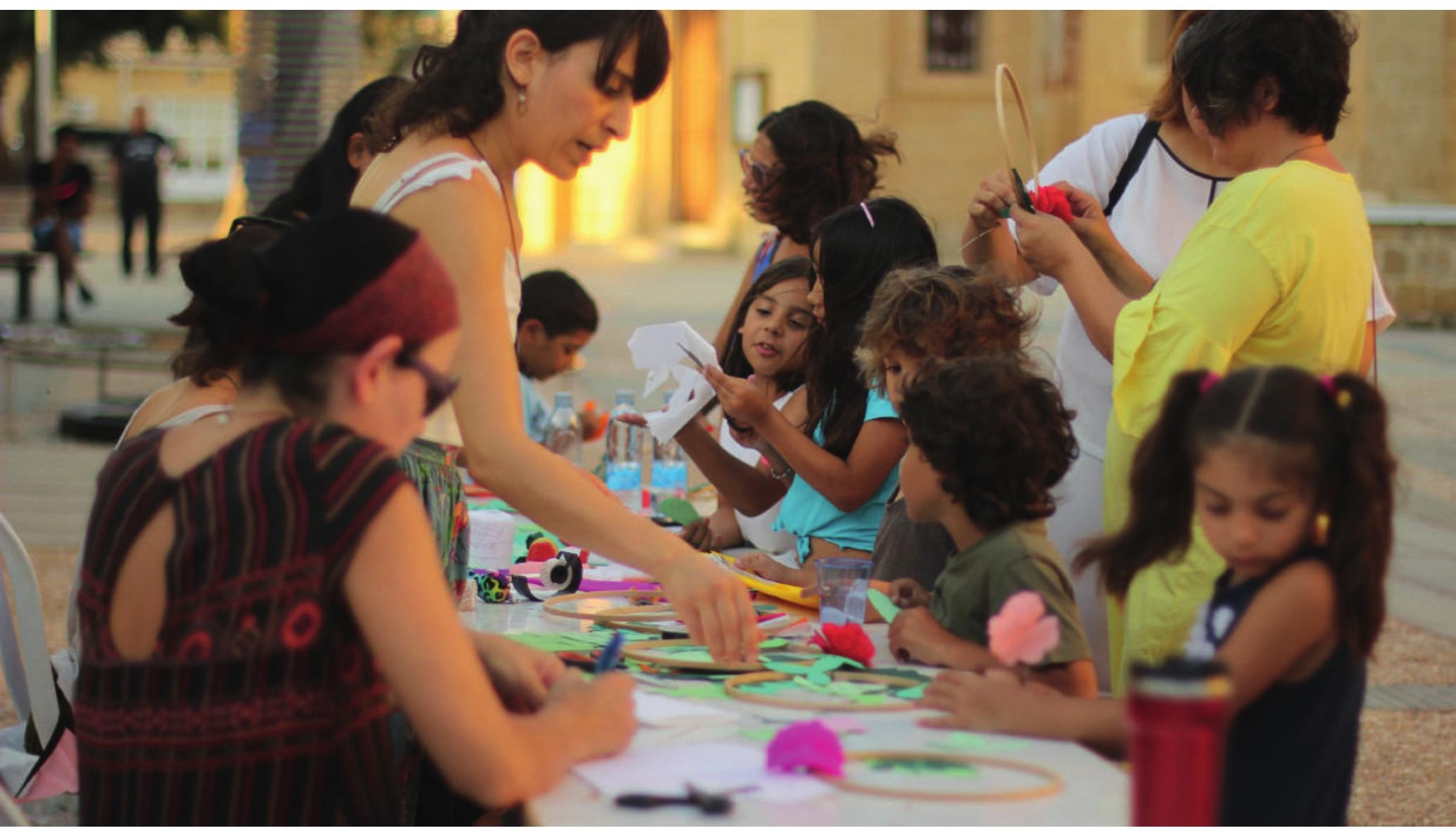

95 | The Journal of Public Space, 4(3), 2019 | ISSN 2206-9658

City Space Architecture / UN-Habitat 

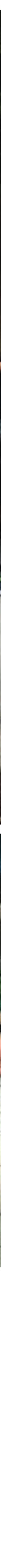

Previous page.

Children Workshop at Church Square.

Photo by Nafsika Hadjichristou.

This page.

Performance in resident's house backyard.

Performance Artist: Cyprus Contact

Improvisation Tribe and Crushed Officers.

Photo by Urban Gorillas.

Poetry installation in resident's garden.

Writer: Costas Manouris.

Photo by Urban Gorillas 
Veronika Antoniou, René Carraz, Yiorgos Hadjichristou, Teresa Tourvas | Urban Gorillas

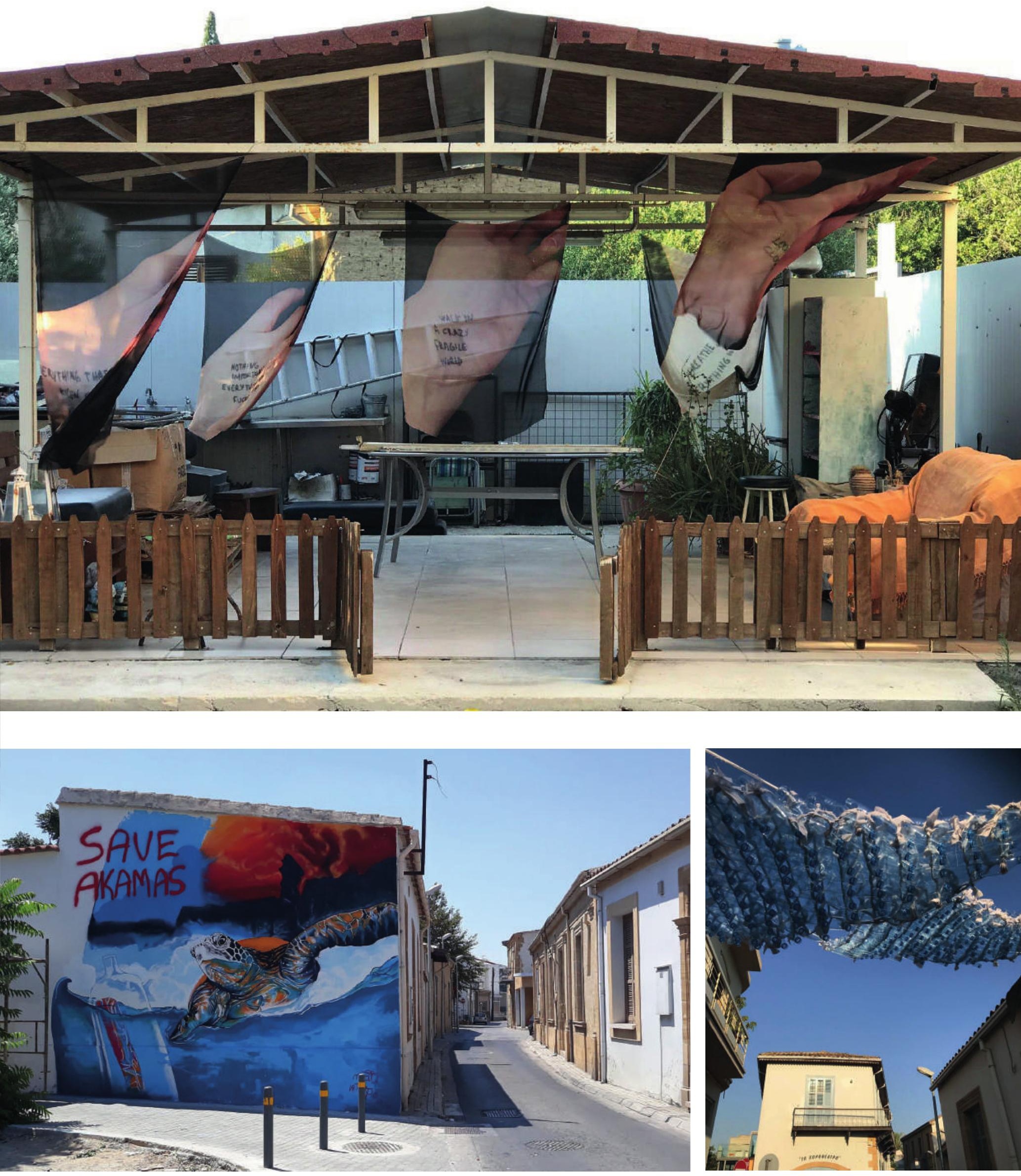

97 | The Journal of Public Space, 4(3), 2019 | ISSN 2206-9658

City Space Architecture / UN-Habitat 


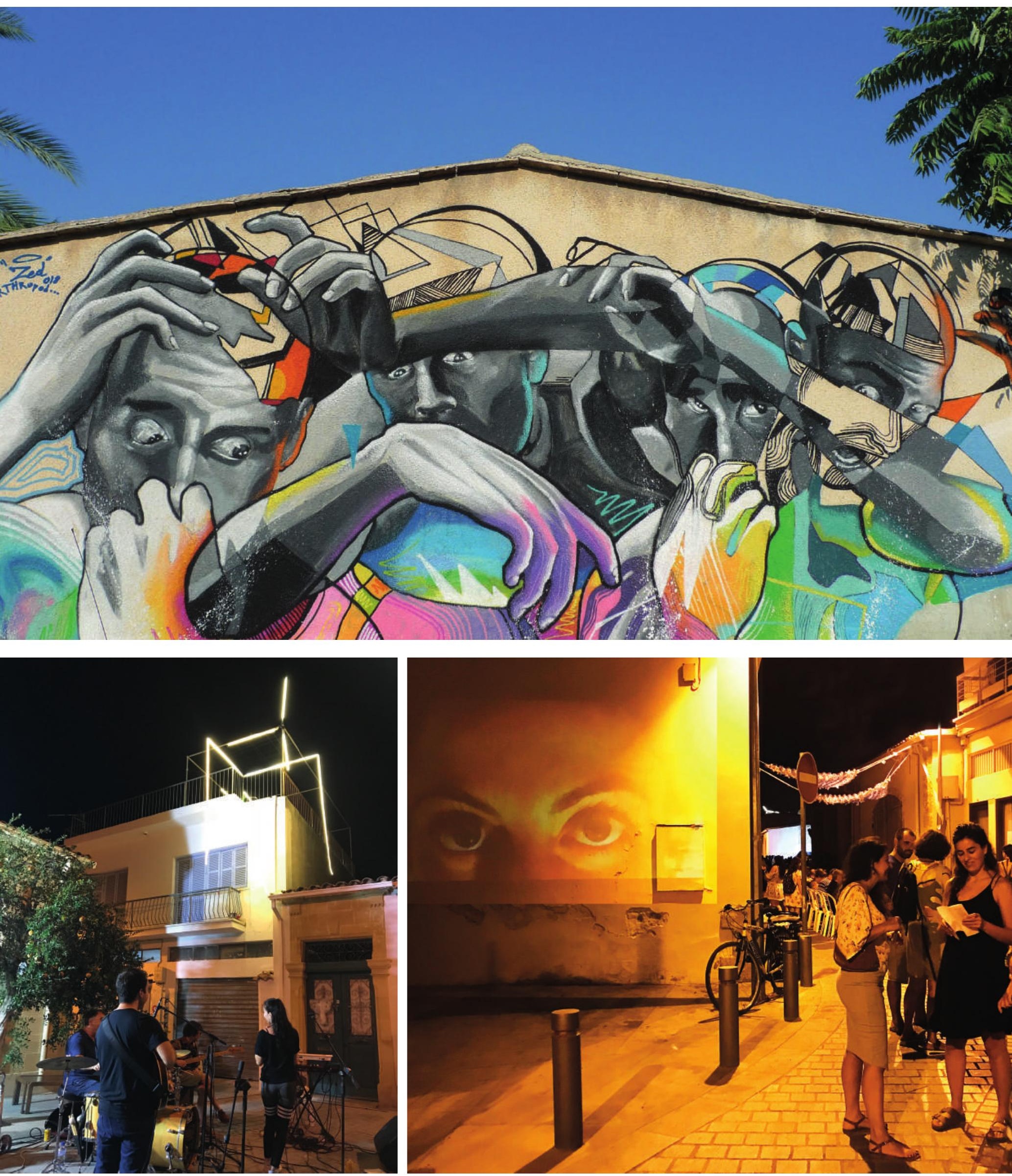

98 | The Journal of Public Space, 4(3), 2019 | ISSN 2206-9658

City Space Architecture / UN-Habitat 
"Adopt an Artist" was an extension of the "Pame Kaimakli" festivals. The 2018 edition of the festival, highlighted the growing gap between the production and enjoyment of art in increasingly privatised and closed art spaces, distanced from the physical public sphere and the wider community, especially the elderly and minority groups.

In the Spring of 2018, UG won a TANDEM Europe grant (https://www.tandemforculture. org/programmes/tandem-europe) which would form the basis of a collaboration with an Italian NGO called NonRiservato (https://nonriservato.it/), a network of artists and creatives from various artistic backgrounds committed to community-engaged actions. The initial idea for collaboration included the hosting - physical and virtual - of artists in people's homes, investigating the idea of the production of art and its display through new methods and spaces. The context of the home as an extension of an open gallery became the basis for an investigation on boundaries between art and the community.

The grant facilitated the hosting and residency of four visiting artists from Italy, sparking the interest of local artists, and developing collaborations and interesting exchanges. The idea also formed the theme for the 2018 edition of "Pame Kaimakli”, “Adopt an Artist". Milano and Nicosia municipalities, and the Cyprus Ministry of Education and Culture also supported the initiative bringing attention to the project.

Work and performances were developed site specifically. Courtyard houses, shops, streets, roofs and abandoned sites, were activated, carving a new public space into the private realm. This created a neighborhood gallery, where the work of artists was co-curated with the active participation of the owners of private spaces. Besides the four artists visiting from Italy, the festival opened up to local artists. As a result, 23 artists were presented in people's houses and 38 projects took place in the neighborhood.

UG paired up hosts and artists in partnerships to develop ideas and projects together, acting as the connecting agent and facilitator between the two. The newly formed partners took on the role of co-curators while taking ownership of their actions. UG provided

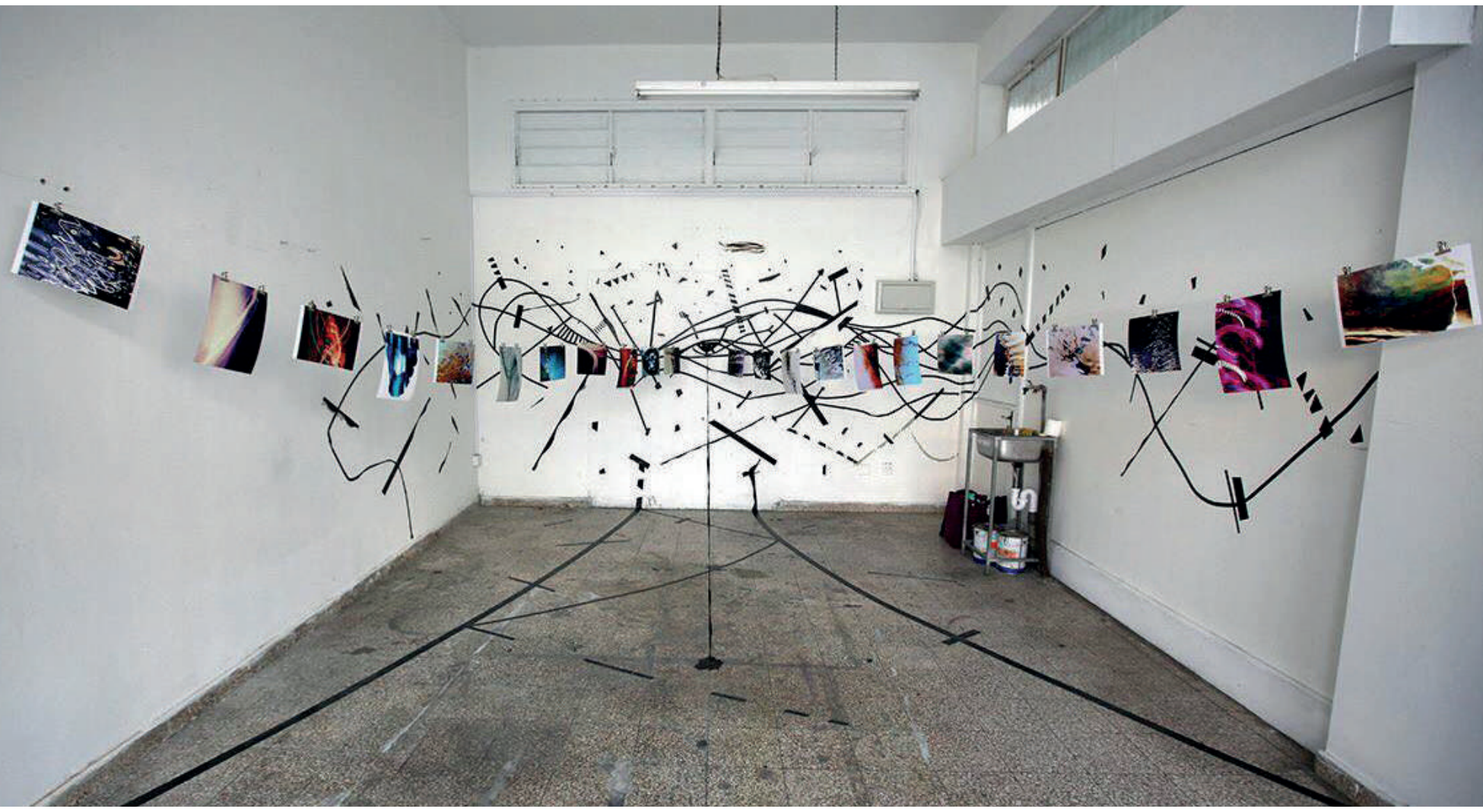

99 | The Journal of Public Space, 4(3), 2019 | ISSN 2206-9658 City Space Architecture / UN-Habitat 
support and facilitated the events, while catalysing connections, opening up the process and engaging the wider community.

In this open model of a socially engaged neighborhood festival, the borders between private and public spaces were temporarily eliminated with the extension of the public space into the otherwise introvert homes, forgotten backyards, private chapels, rooftops, and transformed garages. Events were orchestrated throughout the neighborhood bringing to life unseen spaces and giving life to the neighborhood in an unprecedented way. In our opinion, the success of the project should not be measured in purely quantitative terms, though an unexpectedly high number of people did attend. Success was rather qualitative in nature, creating interactions amongst people diverse in ages, ethnic backgrounds, professional qualifications and interests, together with a desire of the participants to be part of it again.
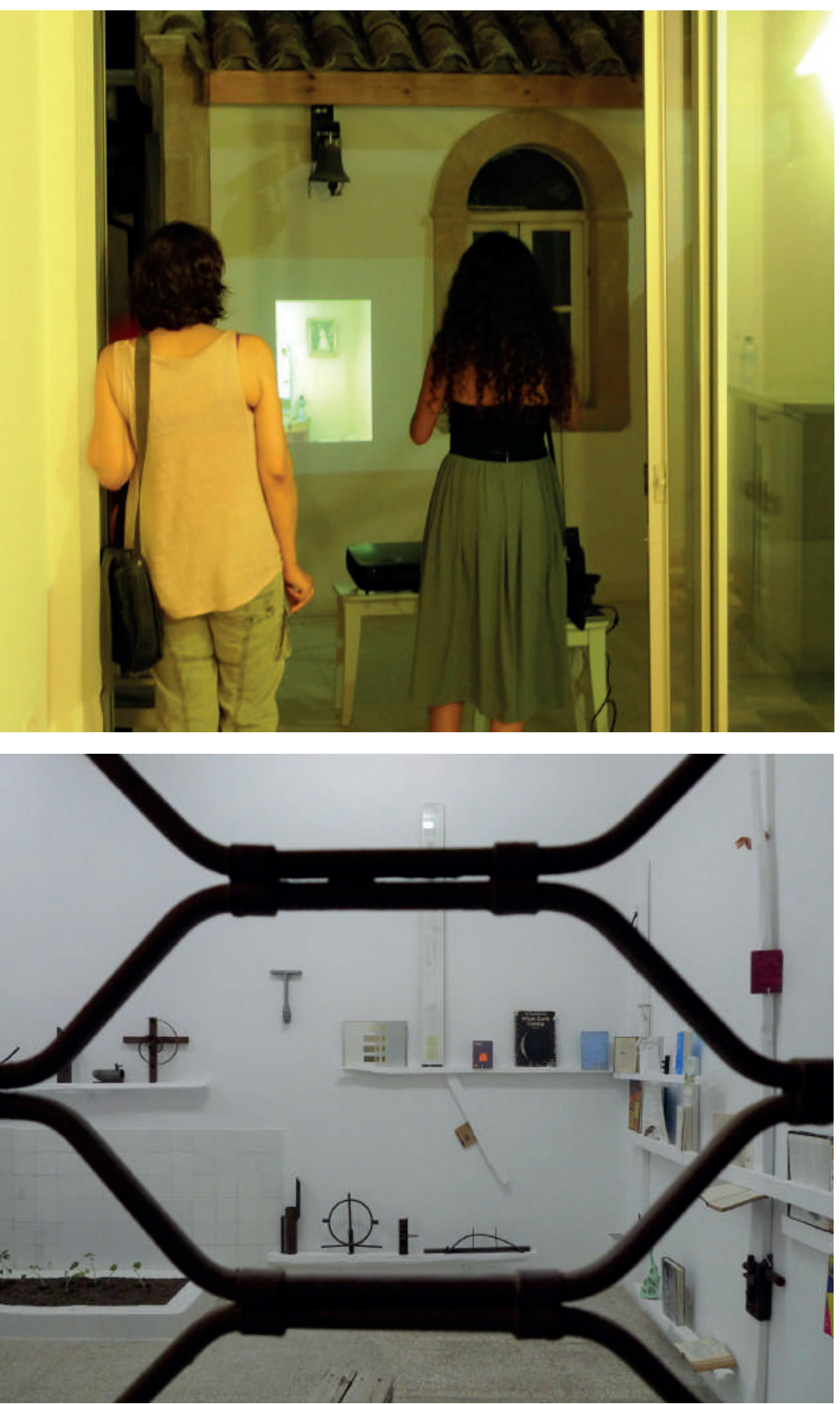

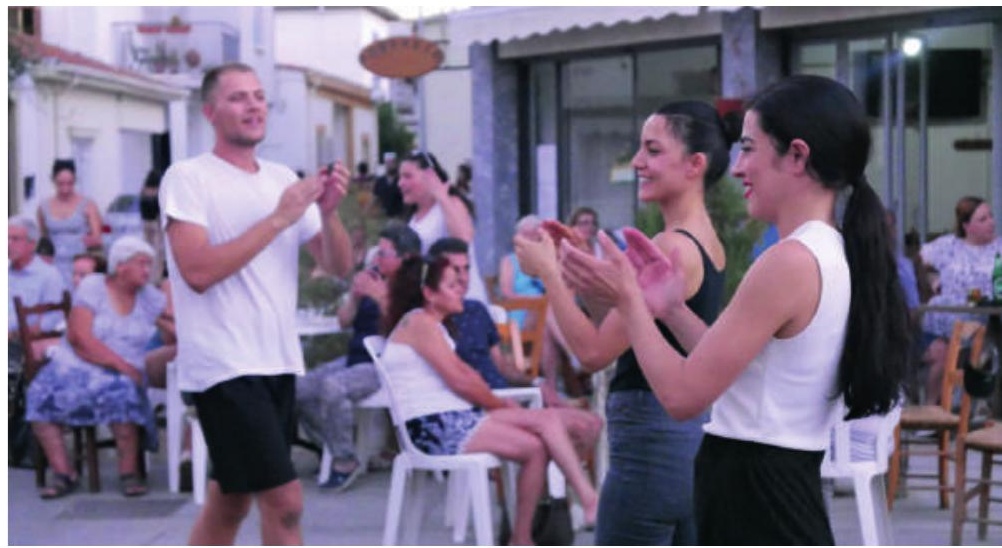

p. 97

Art project in resident's backyard.

Artist: Foteini Pavloglou. Photo by Urban Gorillas Graffiti at car park. Artist: Mathieu Devavry.

Photo by Urban Gorillas

"Shade of Waste" Canopy out of recycled bottles by

Evdokia Demetriou. Photo by Urban Gorillas

p. 98

Graffiti at Car Park.

Artist: Eli Zaarour Work: "Refugees Welcome”.

Photo by Nicos Philippou

Installation at resident's house rooftop.

Artist: Borderlight

Photo by Urban Gorillas

Projections at street level.Video art:Anthropometrie.

Photo by Urban Gorillas

p. 99

Abandoned shop hosts a photography exhibition.

Artist:Adelina Burnescu. Photo by Adelina Burnescu

This page.

Photography exhibition at the chapel.

Artist: Nicos Philippou. Photo by Nikos Philippou

Performance at Church Square.

Performers: Enact Theatre and Dimitris Chimonas.

Photo by Christina Scarpari

Exhibition at Party Contemporary.

Curated by Phanos Kyriacou and Natatalie Yiaxi.

Photo by Nikos Philippou 


\section{Green Urban Lab (GUL)}

http://urbangorillas.org/our-work/urban-interventions/green-urban-lab/

The Green Urban Lab (GUL) was an initiative set up to regenerate public spaces in Cypriot cities. The project intended to raise awareness on the importance of public spaces, a dimension that is lacking in the Cypriot urban culture. It aimed at developing socially sustainable cities through bottom-up initiatives that endorse participatory democracy. The GUL took the form of public installations that were placed at various locations in cities across Cyprus. These installations - through which a series of events, activities, workshops and research took place - were the main tools in regenerating a series of urban public spaces in Cyprus.

The approach adopted for the realization of this mission was the utilization of participatory action research, both in terms of direct urban interventions and observational on-site research. In parallel to the research process that continued throughout the entire GUL project, a range of activities were carried out, varying in scale and approach. These included specialized workshops led by international experts, lectures, an open call for ideas and participation towards local community groups and a series of public events.

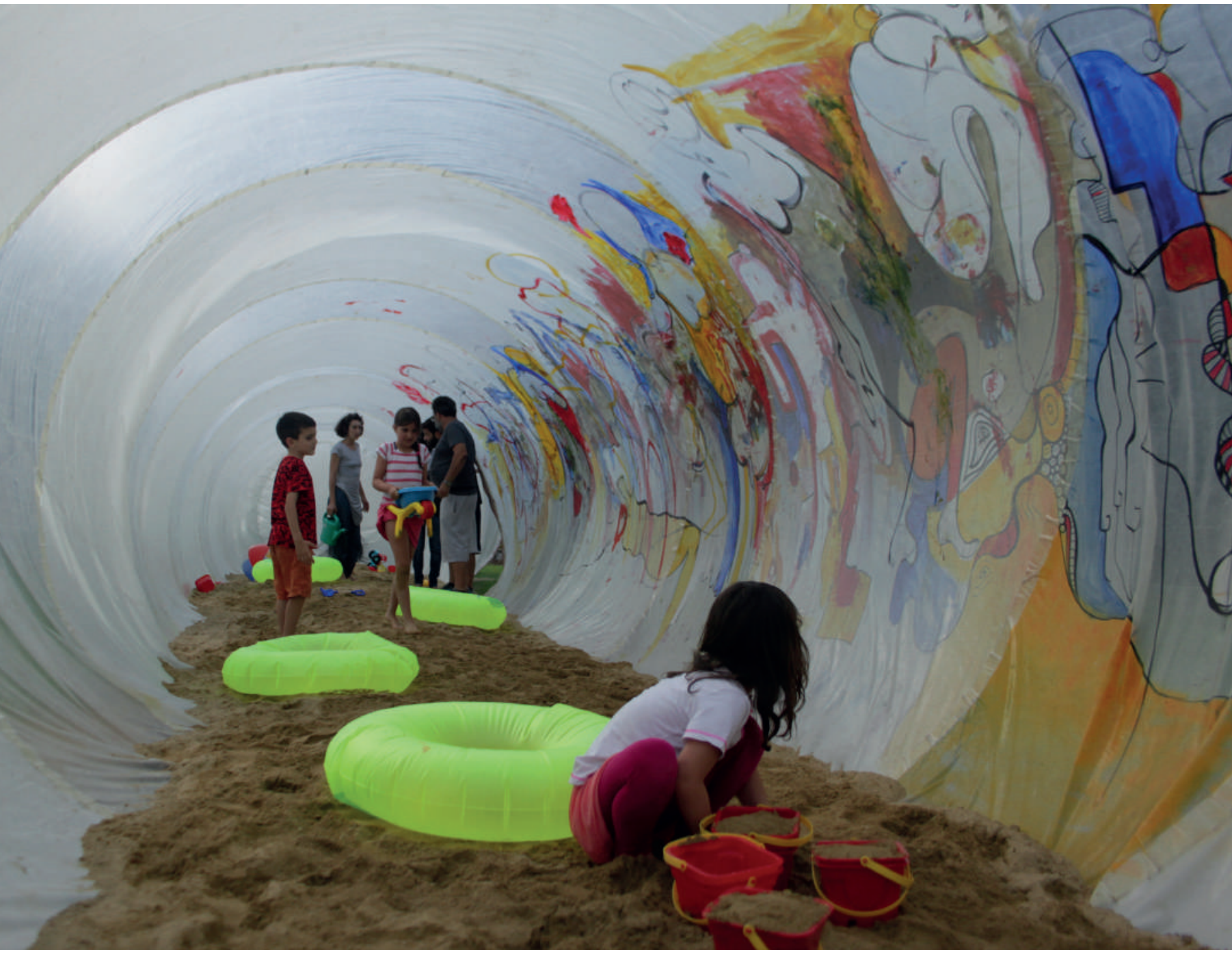

I0I | The Journal of Public Space, 4(3), 2019 | ISSN 2206-9658

City Space Architecture / UN-Habitat 


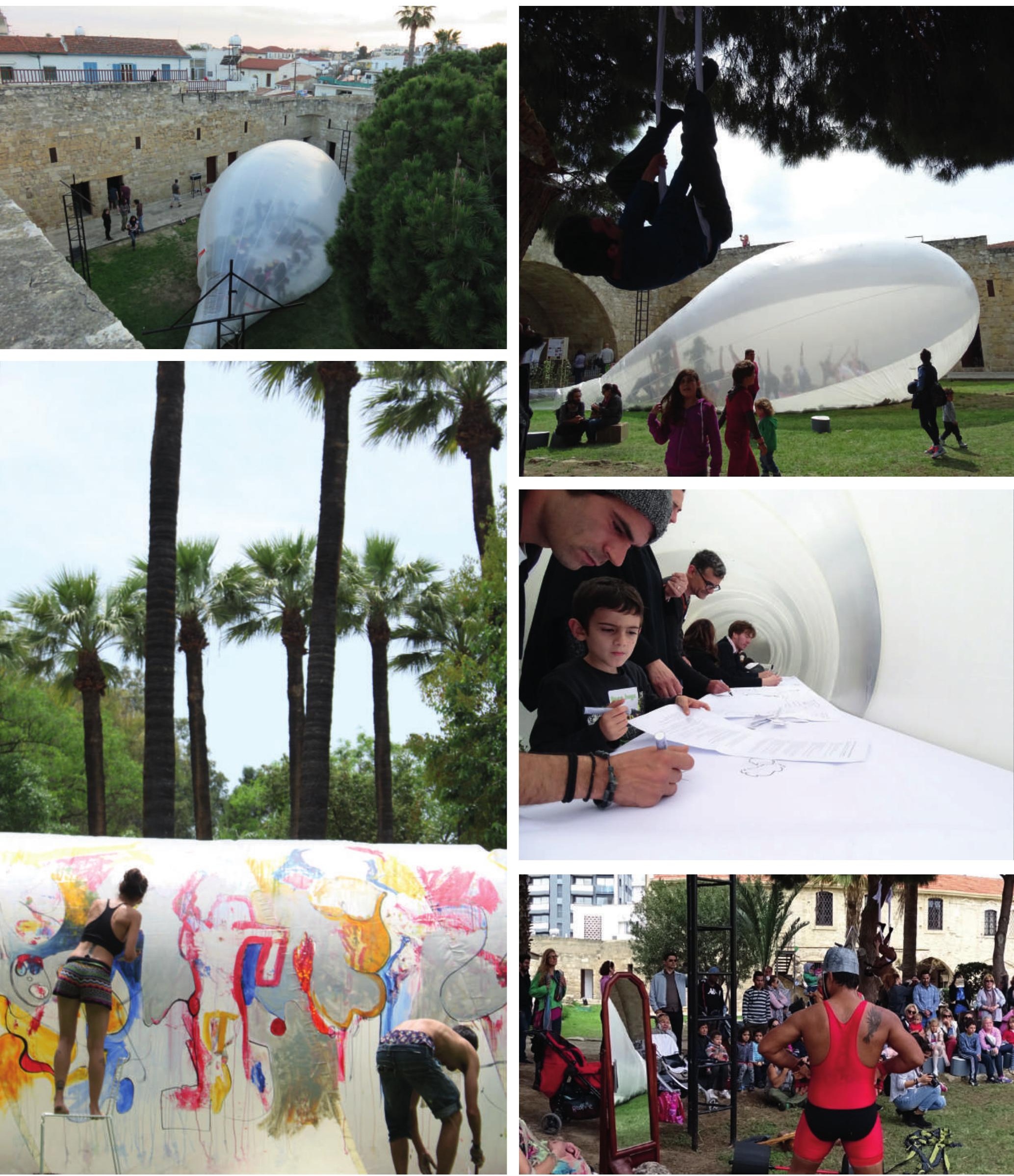

102 | The Journal of Public Space, 4(3), 2019 | ISSN 2206-9658

City Space Architecture / UN-Habitat 
The first workshop, "Inflating the Public l", took place in September 20I4; this workshop initiated the design process and permitted experimentation on inflatable structures through pop-up installations in Nicosia, it was led by Dr. Daniele Mancini. The second workshop, "Inflating the Public II", followed in November 20 I4, focusing on finalizing the design process for the programmed installations, it was supervised by Marco Canevacci, founder of the design firm Plastique Fantastique (https://plastique-fantastique.de/). It was accompanied by a university seminar, "Greening the Public", where students designed and built green urban furniture though the re-use and up-cycling of existing materials.

This process culminated in the "ФouбKóPolis" series of public interventions which were held for two days in each of the four main Cypriot cities between March and April 2015 and co-curated in partnership with Plastique Fantastique. The sites chosen in the coastal towns were important historical landmarks: the castles of Larnaka, Limassol and Paphos, while in Nicosia the events took place in the courtyard of the Cultural Foundation of the Bank of Cyprus. Additionally, the project acquired a bi-communal dimension that was not part of the initial proposal, resulting in the event "Life Inside_Outside a Bubble" at St. Nicholas Church / Bedestan in Nicosia. With this opportunity, the team was able to extend the aims of the project to the Turkish Cypriot community and to bring members of the two communities together through a series of community activities.
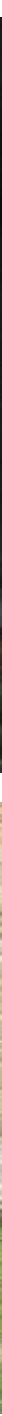
"ФouбKóPolis" was the catalyst event that accelerated the cognitive and emotional attachment to these spaces by citizens. Curated in collaboration with Plastique

Fantastique, we launched an open call, where the feedback was excellent with many people submitting their ideas. We formed a selection committee and chose different works as a way to guarantee diversity and a plurality of content within and around the inflatable structures. Forty-six different activities were presented in total during the timespan of the project.

The interventions, installations, inflatables and festival events were created with the concepts of French philosopher Henri Lefebvre in mind, setting a goal for reinvention of a space into the unexpected. Lefebvre (20l4) stated that "any location can serve as a site

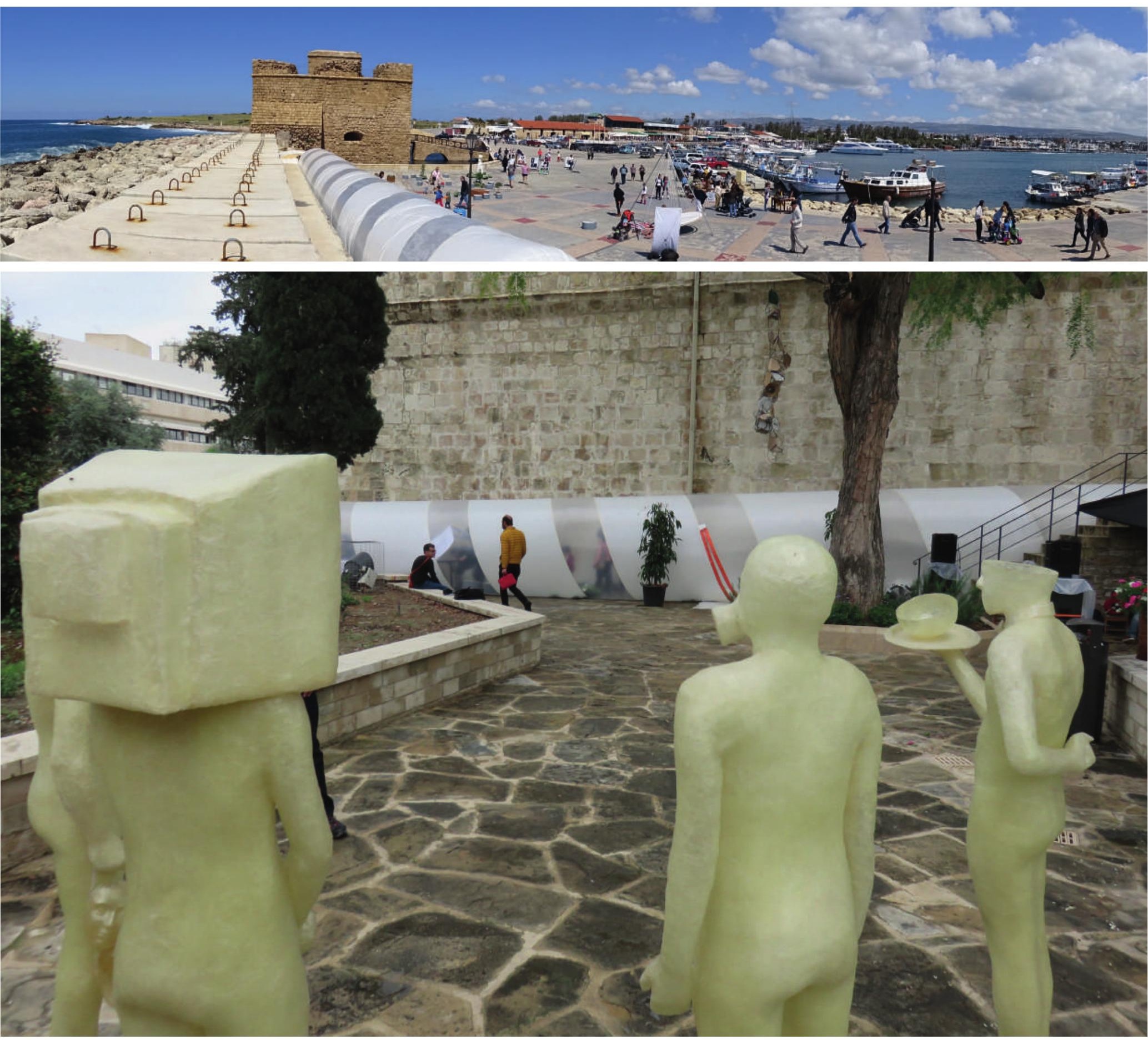

I04 | The Journal of Public Space, 4(3), 2019 | ISSN 2206-9658

City Space Architecture / UN-Habitat 
for pleasure and joy once it has been hijacked, as in the case of a warehouse that becomes a ballroom on theatre". We purposefully and provocatively aimed at 'hijacking' the material presence of history and national identity, and offered it to the people for their enjoyment and active use. By using historical landmarks that are present in the collective memories of most Cypriots, we built our interventions on important historical and political landmarks and challenged their everyday use, or rather the non-use of these sites, located in the historical heart of the cities selected.

In each of the projects, special focus was placed on the notion of the "dissolution of architecture into momentary enjoyment" (Lefebvre, 20I4). The chosen sites were not taken as mere landmarks but were rather thought as a continuation of the city's flows as another urban artery, which should have been freely and invitingly accessed by people. The aspiration was to alleviate the permanent, uninviting and strong attributes of the monuments by creating exactly the opposite situation with the light, ephemeral and transparent inflatable structure. The introduction of joyful events into the city through playful design techniques had the potential to produce perception changes and new usages, thus turning under-utilized public spaces into vibrant places suitable for public life (Merry and Carraz, 2015). The Green Urban Lab project was made possible through funding from the EEA Grants/Norway Grants. The project was fully documented and a book with project results was published (Carraz et al., 2018).

\section{p. 101 \\ Fouskopolis at the Youth Festival, Municipal Gardens. Featured artists: Mathieu Devavry and Baroque Rococo. Photo by Apostolia Michael.}

\section{pp. 102-103}

Fouskopolis in Larnaca Castle.

Photo by Urban Gorillas and Stavri Papadopoulou. Fouskopolis at the Youth Festival, Municipal Gardens. Featured artists: Mathieu Devavry and Baroque Rococo. Photo by Apostolia Michael Fouskopolis in Limassol Castle. Photo by Urban Gorillas.

Fouskopolis in Larnaca Castle: Featured performers: Pritz Pratz goes into the sacred Oak.

Photo by Stavri Papadopoulou

\section{p. 104 \\ Fouskopolis in Paphos Castle. Photo by Stavri Papadopoulou Fouskopolis in Limassol Castle: Featured artist work:Alexandros Yiorkatzis. Photo by Stavri Papadopoulou}

This page.

Fouskopolis in Limassol Castle. Photo by Stavri Papadopoulou Fouskopolis at the Bank of Cyprus Cultural Foundation.

Photo by Stavri Papadopoulou
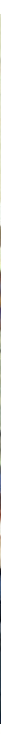

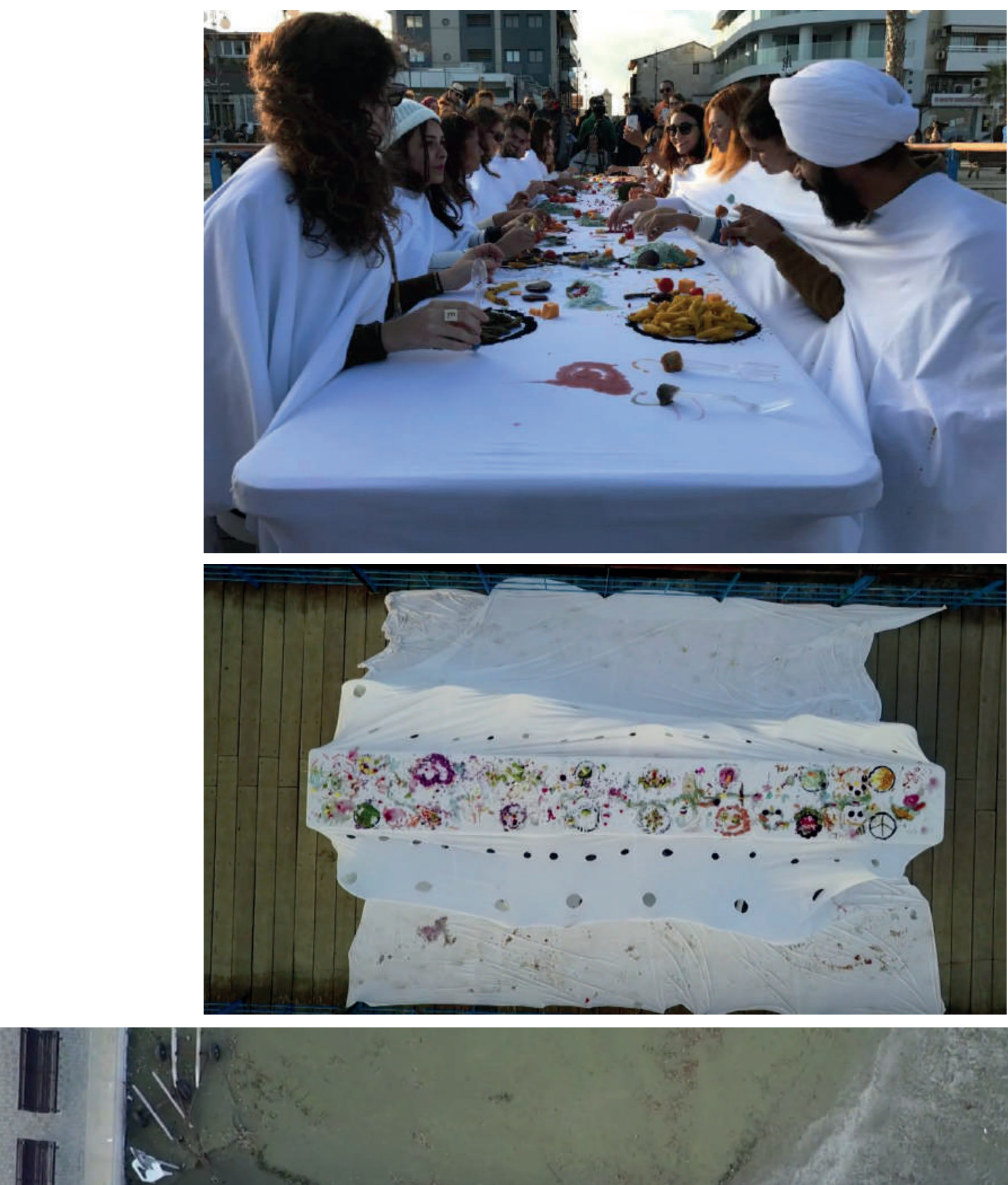


\section{Urban Dinner}

(Part of the Urban Spectacle series)

http://urbangorillas.org/tag/urban-spectacle/

Photo credits: Urban Gorillas

The "Urban Spectacle" public intervention series was a project consisting of 5 urban interventions across different public spaces in Cyprus. The urban installations and performances explored the increasing relationships between the urban landscape and a) art and activism, b) architecture and urban design and c) performances and installation. The performative acts aimed in bringing forward the importance of public spaces in the city. What if, the public space in your neighborhood could be an extension of your house? What if the city was really yours, and we could start to claim ownership on what is arguably 'public'? The diverse forms of artistic projects took the form of activism because they challenged peoples' perceptions about their contested environment, particularly in the pertaining issues of division, segregation, social inequalities, regarding the usage of public space.

The interventions explored human interactions within public spaces and examined the relationships between the observer, the performer and the spatial setting in an attempt to create new negotiations amongst them. Through various actions, the city is explored both as a spectator and performer in settings where the boundaries between public and private, physical and symbolic, start to dissolve and intervene with one another. The aim was to challenge the citizens from stereotyped ways of seeing and interacting not only with one another but also with their urban public spaces. A "stage" in the respective public spaces offered a new spatial organization in the assigned location and entailed an element of surprise for the passersby.

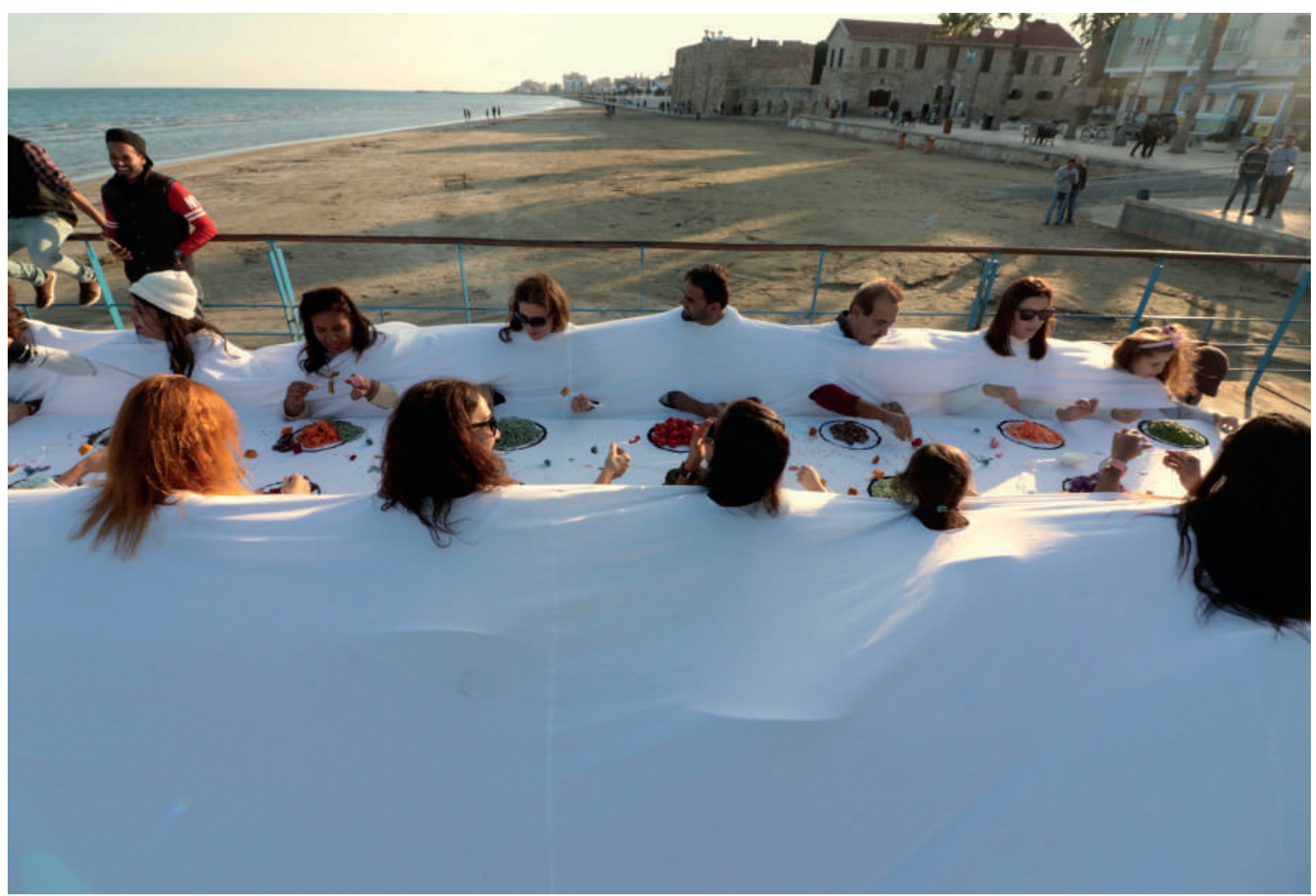


The "Urban Spectacle" series involved the collaboration with young Cyprus-based artists whose work challenges the observer juxtaposing her into a spectacle of the urban scene, different from the mass-produced consumerist displays omnipresent in our urban culture. Art in these intervention series was presented outside formal institutions and was made available in open public spaces for free in the form of installations, live painting performances, performing arts and graffiti.

These were small scale, extremely low cost urban aesthetic experiments taking place in open public spaces without formal consent and documented all through video media: Curated by Veronika Antoniou \& Mathieu Devavry and installed by the UG team, "Urban Dinner" was an "Urban Spectacle" set at the Larnaca Pier depicting a group of people having dinner in the city, in this unexpected location. The setting was more like a theatrical stage with the sea as the backdrop.A dinner with friends or strangers is a moment where we all come together to share. The desire to relate with each other as human beings and adopting the act of eating as an engaging participatory experience was the focal thematic of this act. The plot was centered around food as an element that heightens all the senses. This was accentuated through the installation as the emphasis on the colours of food, on noises, smell, taste and touch were negotiated throughout the dinner.

The act of dining in a public space, under a unified white cloth equally highlighted the issues of participation, engagement and belonging in public spaces, that we all share on equal terms. Covering the table and participants with one white tablecloth created in addition, a sense of equality and unity amongst all dinner guests.

A series of eating instructions were given to guests in order to facilitate the envisioned interactions between people. Each guest on the table had one type of food in his plate with a distinctive colour. During the dinner, guests shared their food with one another and as colours began to mix, the guests were indulged in eating different food offered to them. Consuming, preparing and sharing food are primary human activities. Food is becoming a central theme in UG's investigations of how we can create connections with people that overcome social, cultural and ethnic divisions. Our food-based projects propose a reexamination of the ways we connect and share within the society as a whole. It suggests a more active engagement within public urban spaces. By the conclusion of the event, the table was transformed into a canvas of a colourful, unified creation. Through art and intercessory experiences, the project proposed new channels of communication and sharing between people.
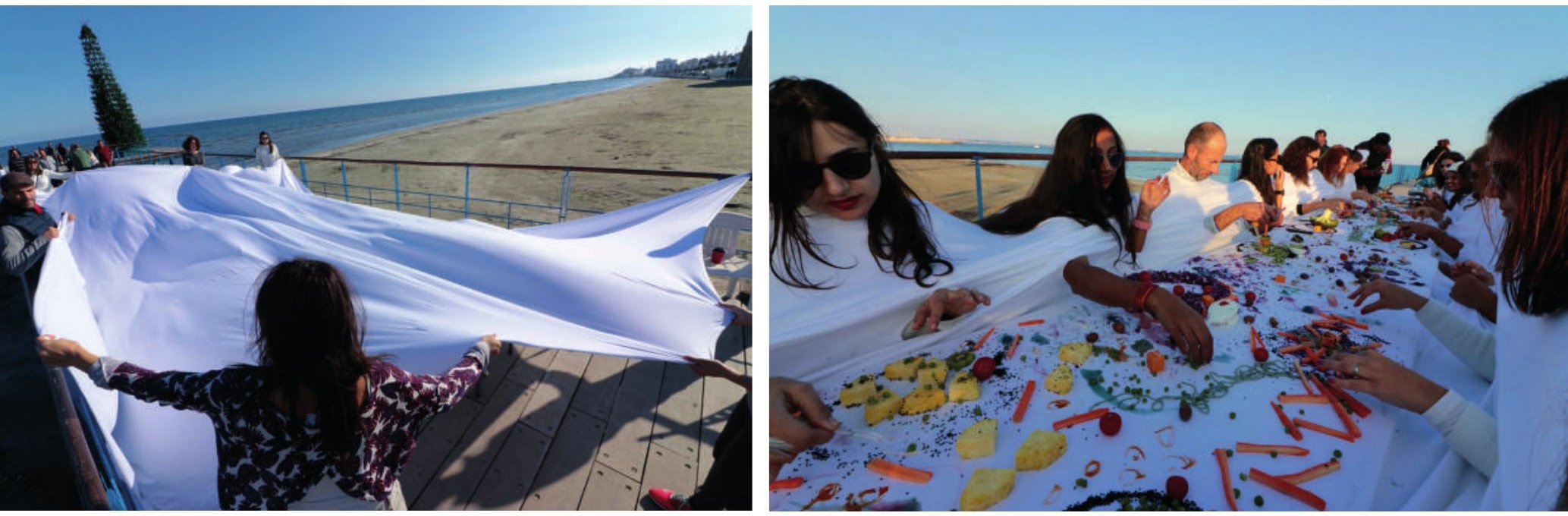

108 | The Journal of Public Space, 4(3), 2019 | ISSN 2206-9658

City Space Architecture / UN-Habitat 


\section{Open Kitchens}

http://urbangorillas.org/our-work/urban-interventions/open-kitchens/

Photo credits: Nafsika Hadjichristou, Ana Vives

"Open Kitchens" is a co-creation tool in the form of cooking and dining launched by Urban Gorillas. It aims to enhance the participatory aspect of the upcoming "Pame Kaimakli" 2020 festival by building a dialogue amongst diverse groups of people in a relaxed and inclusive manner. At the same time, it celebrates the cultural layers of the neighborhood of Kaimakli through the launch an open invitation for sharing stories, visions and tasty food.

"Open Kitchens" took place in July 2019 and is a continuation of a series of events presented in previous "Pame Kaimakli” editions ("Open Doors", “Open Windows", "Open Courtyards": for details check "Adopt an Artist" description). An open call addressing Kaimakli residents, artists, social practitioners, activists, academics was launched asking the public for the development of activities together with the migrant community of the area. "Open Kitchens" was a unique dining experience where residents of Kaimakli, from diverse ethnic backgrounds and a passion for cooking, were hosted in the homes of local residents' to stage dinners from around the world. Chefs from Italy, Somalia, Japan, Syria, Philippines, China, and the Carribean were hosted in seven houses in the neighborhood. In total, 77 participants from 15 different nationalities, from diverse paths of life and ages from 15-86 years old participated and distributed evenly amongst them the seven dinners.

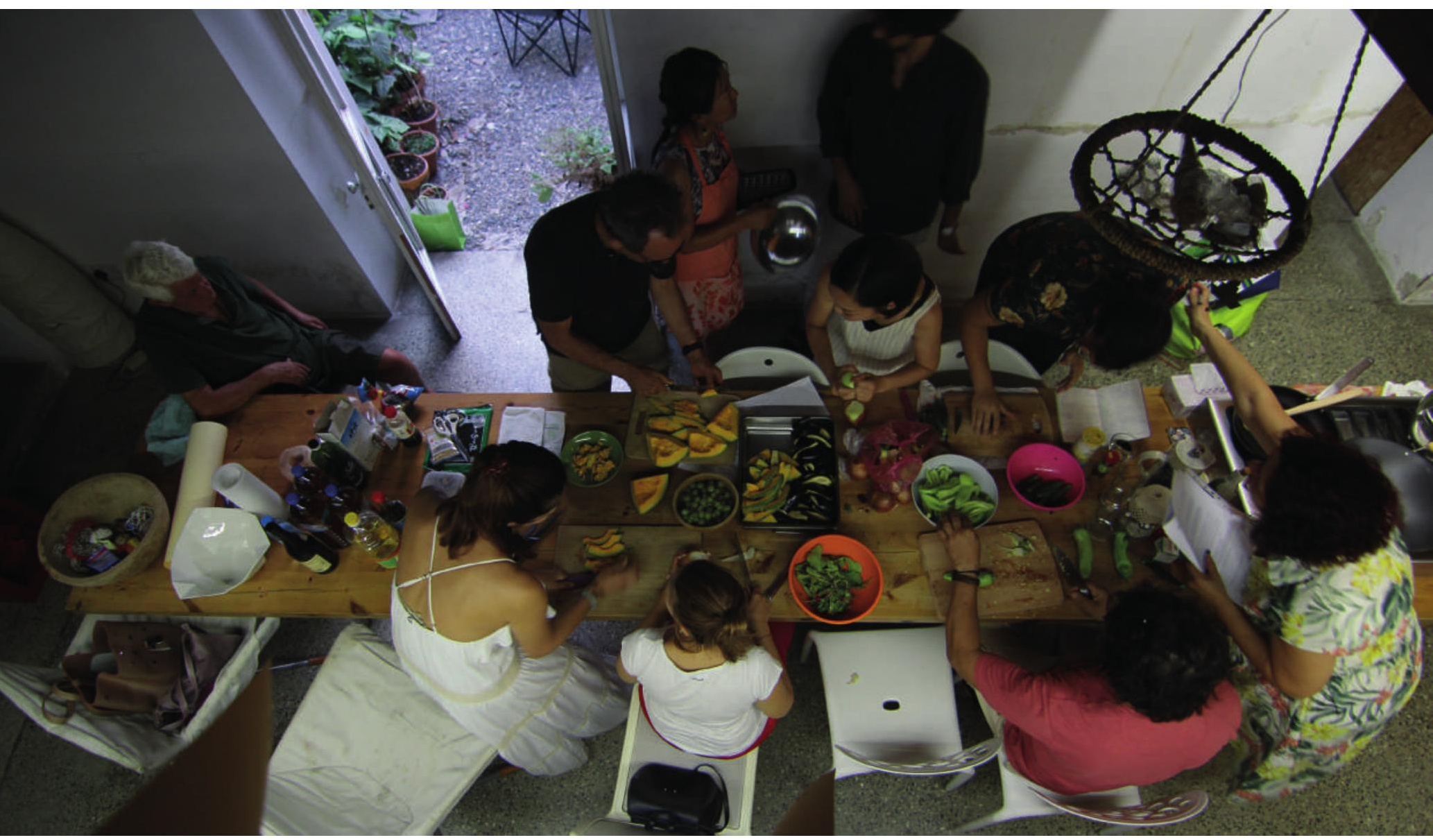



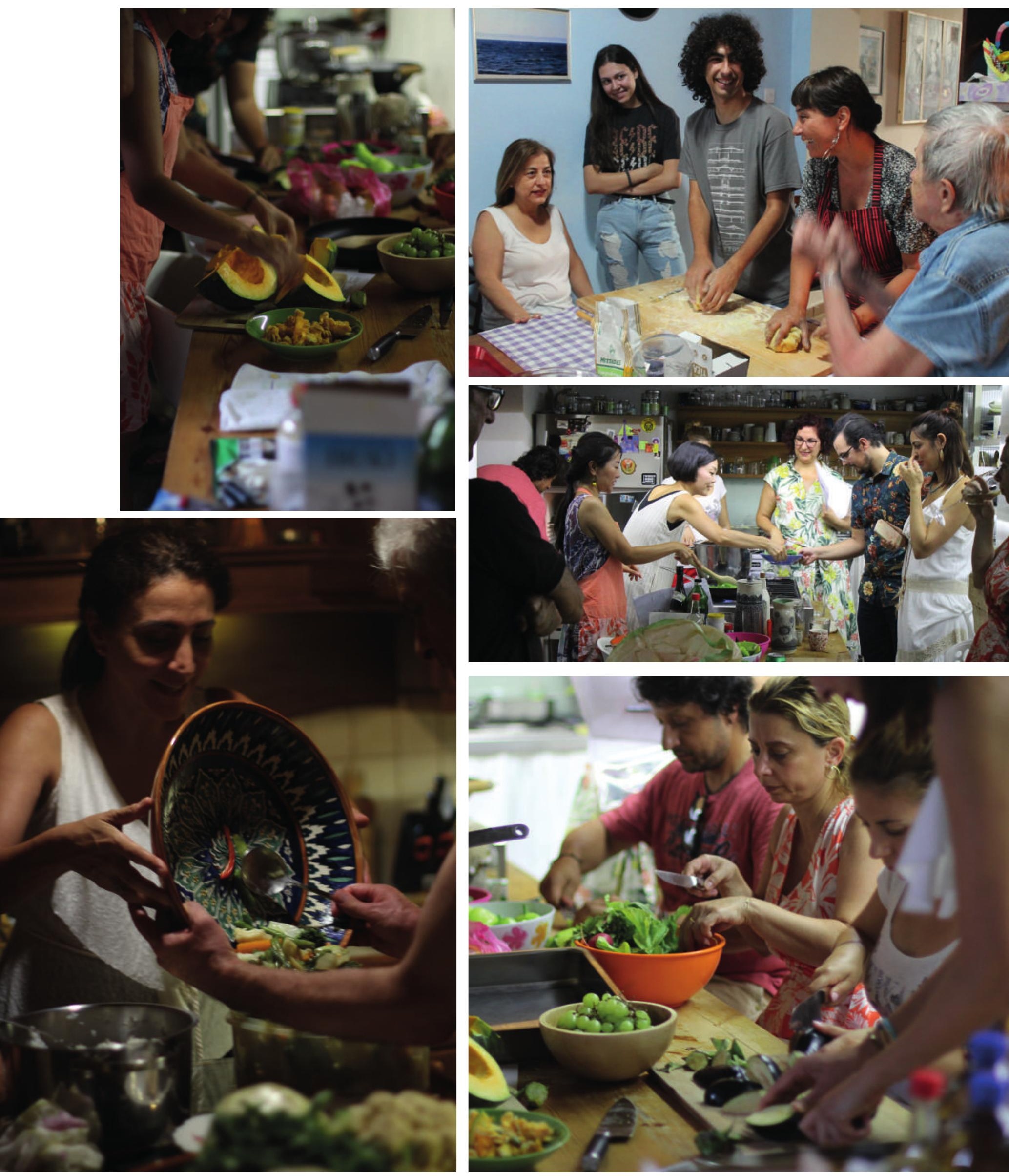

I I 0 | The Journal of Public Space, 4(3), 2019 
The food prepared and served was intentionally vegetarian in order to further increase awareness about the impact of raising animals while in a climatic emergency state, and a proposal to move towards a more sustainable lifestyle. This was challenging for chefs and participants, yet unsurprisingly, and according to the participants, it was a successful attempt demonstrating alternative, healthier and possibly tastier eating habits.

After the selection of the participants, UG acted as the mediator between invited chefs and hosts with regular meetings in order to finalize the identity of the activity based on the uniqueness of each chef and host. UG also acted as a matchmaker between involved participants and hosts, in an attempt to distribute people of different ages, nationalities and backgrounds evenly in the 7 houses.

The gathering and the assignment of the participants to houses and chefs took place at the traditional coffee shop at the church square of the old Kaimakli neighbourhood.All the participants were involved in the preparation and the cooking following the instructions of the chefs. During the cooking and the ensuing dinner, the participants discussed various issues about the act of eating as a catalyst for socializing and bringing together people, that otherwise would have never found an opportunity to meet. They also brainstormed with ideas for the forthcoming festival.

Even though dining with complete strangers, the process of food preparation made it easy to connect. People shared relevant stories personal, communal, ethnic expressed through dancing and singing and other spontaneous activities. The moderators of each group documented the ideas and proposals and shared them with the participants during a wrap-up gathering at the end of the event. This took place back at the coffee shop, where the traditional local sweet "mahalepi" was served. The participants expressed an unprecedented enthusiasm for the whole event, while through testimonies, it seems that it might have been the first time that many immigrants felt like part of the neighborhood's community.

For many participants, the communal cooking echoed the lost tradition of the celebration of weddings, where the community helped in the preparations in any possible way that included cooking together to celebrate and indulge to a collective joy in the settlement. Open Kitchens has been a research tool for UG, where input from the discussions over dinner provided information on how to best plan the next edition of the "Pame Kaimakli" festival adopting the themes of food culture and integration of disadvantaged communities.

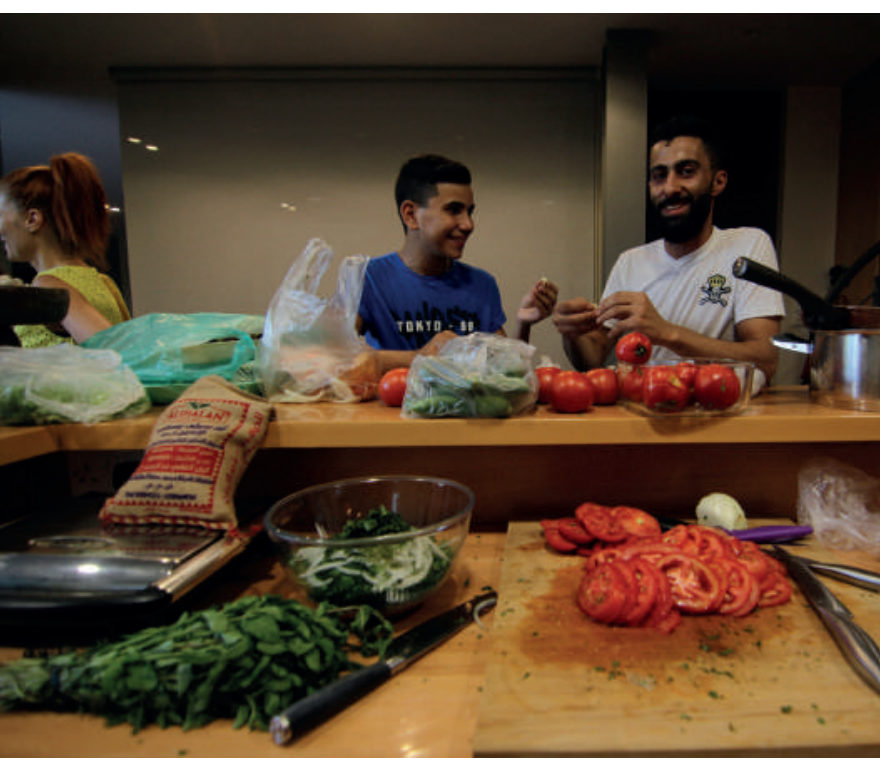

| I |

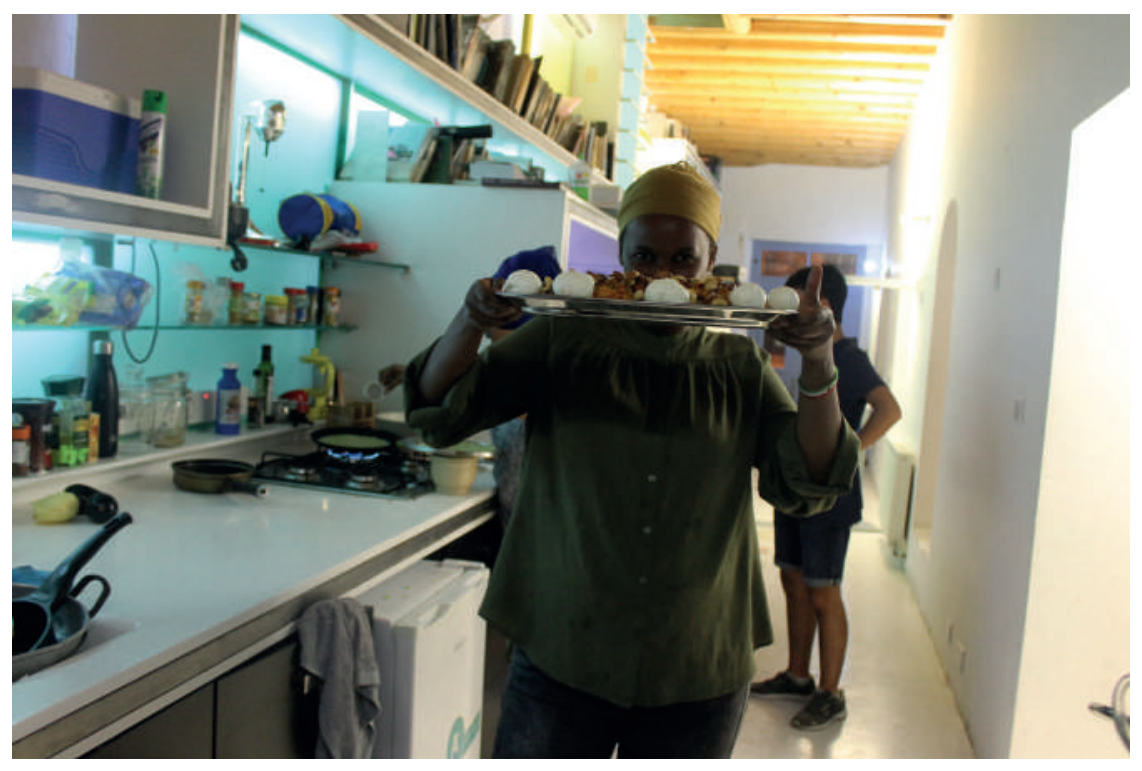

ISSN 2206-9658 City Space Architecture / UN-Habitat 

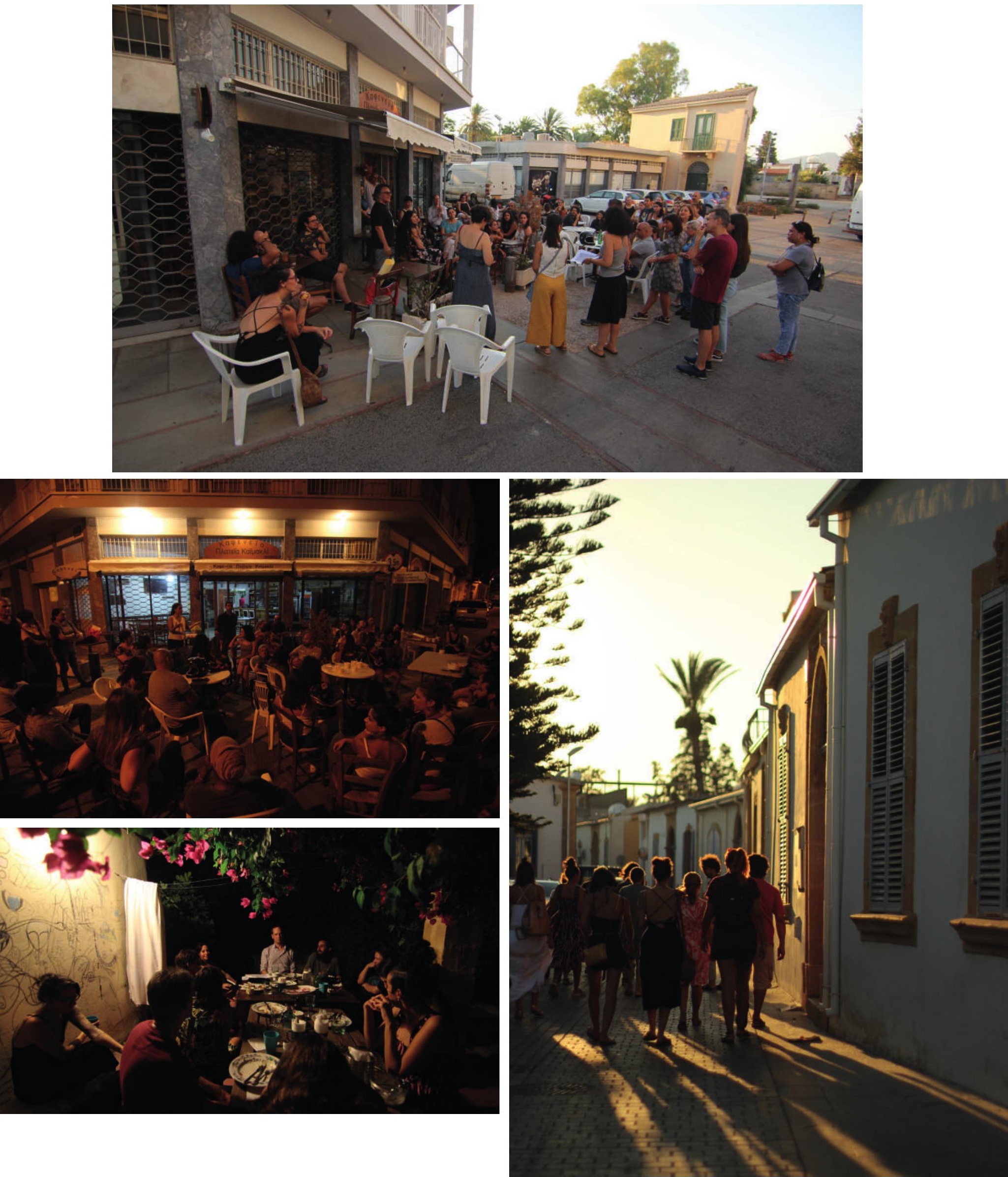

II2 | The Journal of Public Space, 4(3), 2019 | ISSN 2206-9658

City Space Architecture / UN-Habitat 


\section{Green Kitchen Bus}

http://urbangorillas.org/our-work/urban-interventions/green-urban-kitchen-bus-2/

Photo credits: Urban Gorillas

The Green Kitchen Bus was realized in 2014 and was the first action to be implemented by Urban Gorillas. This project was the result of a collaboration with AKTI an NGO active in promoting sustainable development, where UG proposed an urban intervention to create awareness of the Tiganokinisi campaign of AKTI, regarding the recycling of cooking oil.Tiganokinisi was a program converting used cooking oil into biodiesel. The program's aim is to encourage the public to participate actively in the process of converting waste cooking oil into biodiesel for a more sustainable and green living in the community.

With a 2,000 euro support from the Fulbright Foundation, the UG team was in search of low-cost alternatives in order to create an urban intervention with the maximum impact. We turned our attention into a metal junk yard, looking for interesting discarded objects, where we detected an out-of-use bus; it was instant epiphany: we could not have thought of a more effective tool to promote the idea of biodiesel conversion!

After several weeks of working in the junkyard, UG converted this old and discarded bus into an accessible green haven. Inside, the bus we laid a scene of a "green kitchen" planted with vegetables and herbs, food, cooking equipment and utensils. On the outside, the bus turned into a surface for an art project to be displayed. With the collaboration of wood print artist Evgenia Vasiloudi, her flower series of "Natural Conversation" was exhibited on the bus through stencils and painting techniques.

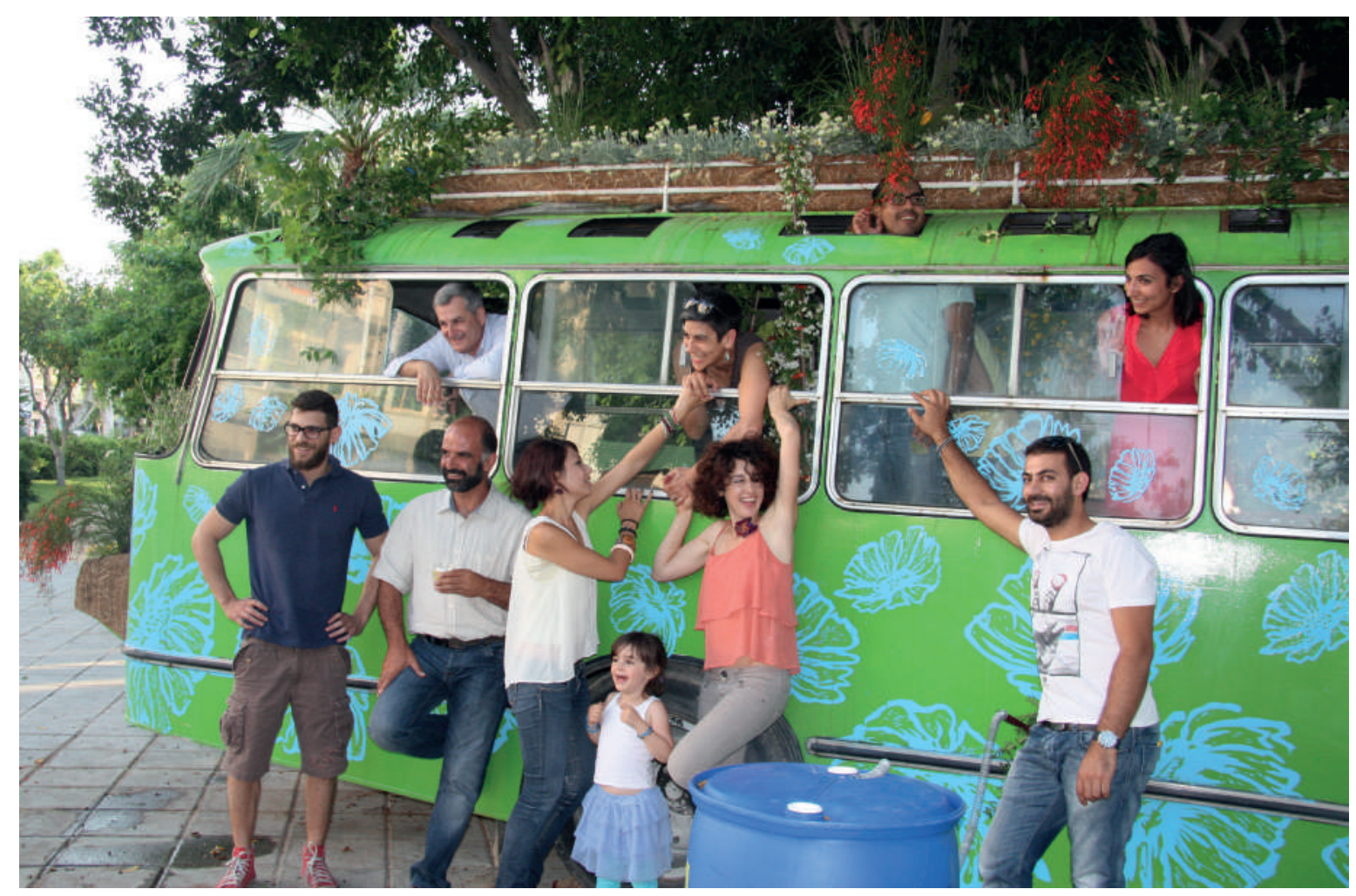

II3 | The Journal of Public Space, 4(3), 2019 | ISSN 2206-9658 City Space Architecture / UN-Habitat 

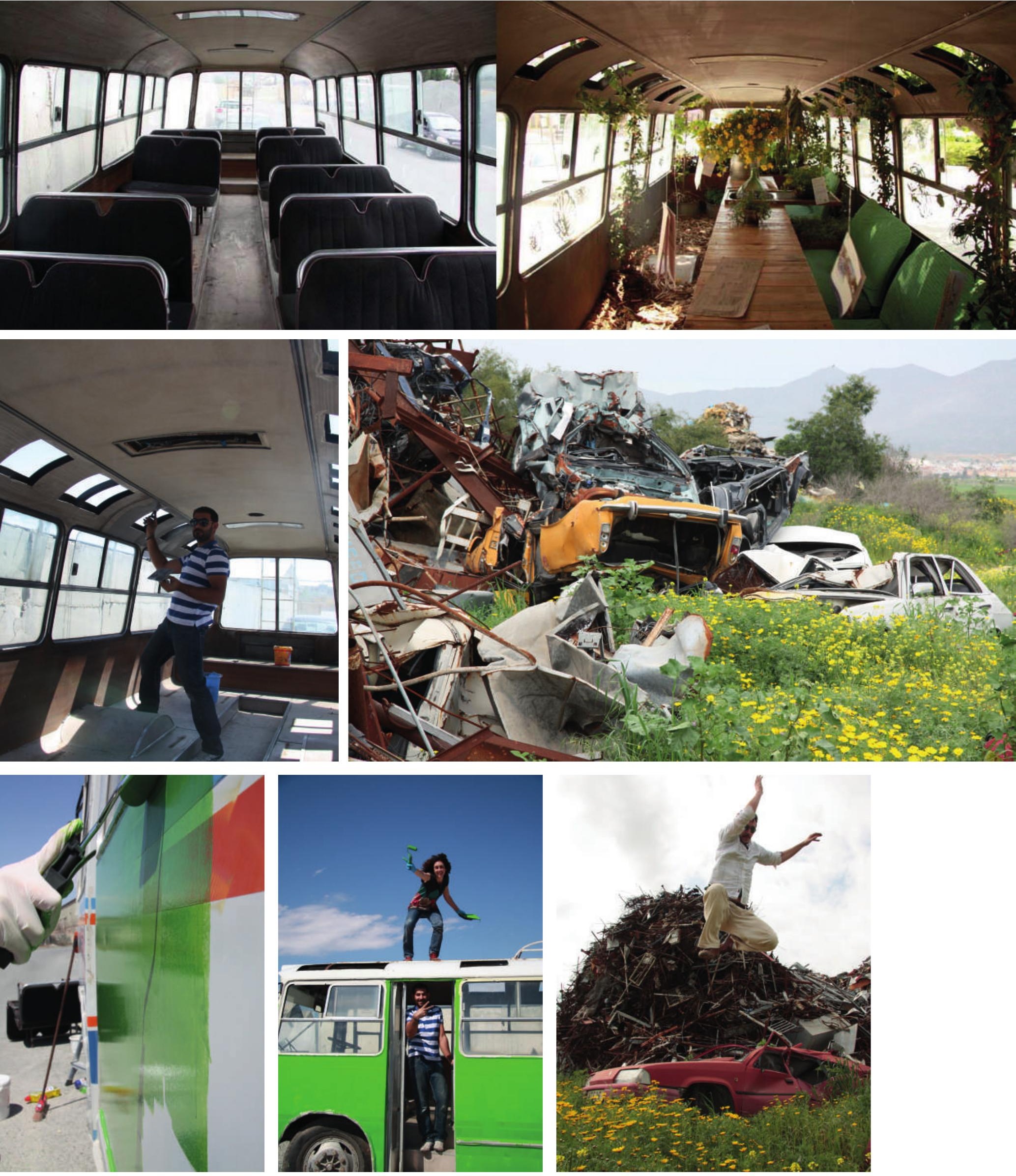

II4 | The Journal of Public Space, 4(3), 2019 | ISSN 2206-9658

City Space Architecture / UN-Habitat 
Veronika Antoniou, René Carraz, Yiorgos Hadjichristou, Teresa Tourvas | Urban Gorillas
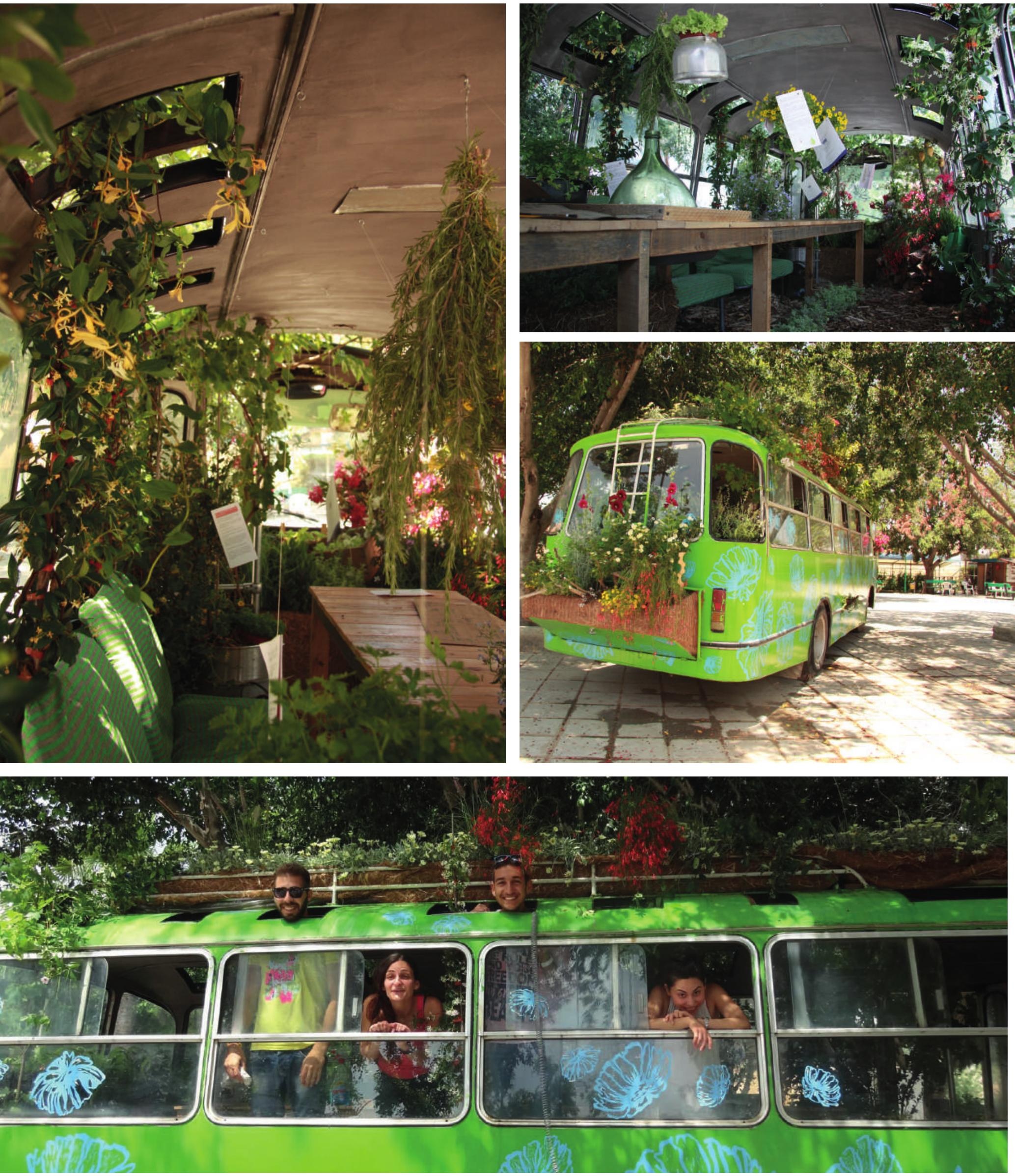

II5 | The Journal of Public Space, 4(3), 2019 | ISSN 2206-9658 City Space Architecture / UN-Habitat 
The "Green Kitchen Bus" raised the issue of public transport and more generally dealt with the promotion of sustainable lifestyles, alternative mobility options, recycling materials, and home-grown vegetable gardens. At the same time it offered ephemeral shaded seating areas in two locations: in a large parking place in Limassol city and in $\mathrm{Ag}$. Demetrios park in Nicosia, both lacked public benches.

The public installation offered the public a fresh perception on the use of public spaces and generated creative forms of social interactions while promoting a renowned artist's work on the street level. It has rendered two sites with both familiar and unprecedented urban vibes, scripting a new urbanscape for its inhabitants creating common stories and memories. These ephemeral and spontaneous injections into the two sites, enriched them with qualities of momentary urbanism.

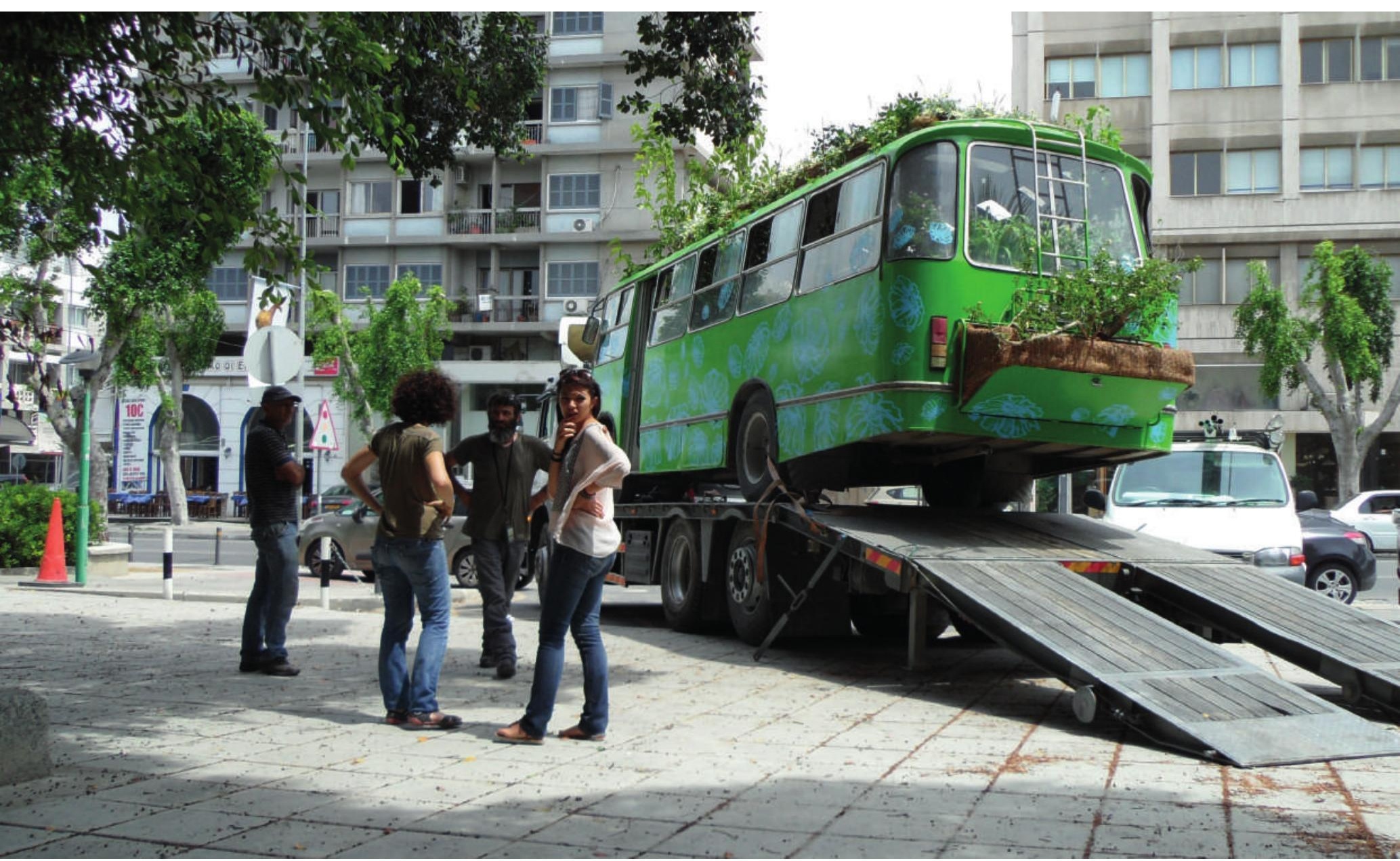

